1971

\title{
Consumer Sensitivity to Interest Rates: An Empirical Study of New-Car Buyers and Auto Loans
}

James J. White

Frank W. Munger

New York Law School, frank.munger@nyls.edu

Follow this and additional works at: http://digitalcommons.nyls.edu/fac_articles_chapters

Part of the Banking and Finance Law Commons, and the Consumer Protection Law Commons

\section{Recommended Citation}

Michigan Law Review, Vol. 69, Issue 7 (June 1971), pp. 1207-1258

This Article is brought to you for free and open access by the Faculty Scholarship at DigitalCommons@NYLS. It has been accepted for inclusion in Articles \& Chapters by an authorized administrator of DigitalCommons@NYLS. 


\title{
CONSUMER SENSITIVITY TO INTEREST RATES: AN EMPIRICAL STUDY OF NEW-CAR BUYERS AND AUTO LOANS
}

\author{
James J. White* and Frank W. Munger, Jr.**
}

\section{INTRODUGTION}

\begin{abstract}
A LTHOUGH it has never been clear whether the consumer needs to be protected from his own folly or from the rapaciousness of those who feed on him, consumer protection is a topic of intense current interest in the courts, in the legislatures, and in the law schools. A number of recent court decisions have attempted to attack problems confronting the consumer; ${ }^{1}$ unfortunately, these judicial efforts have succeeded primarily in disclosing the limitations in the courts' ability to deal with such problems. State and federal legislative bodies have pursued more carefully designed remedies. Congress has passed the Truth-in-Lending Act; ${ }^{2}$ the National Conference of Commissioners on Uniform State Laws has proposed the Uniform Consumer Credit Code; ${ }^{3}$ and many states have enacted retail installment sales acts ${ }^{4}$ to update and supplement their long-
\end{abstract}

- Professor of Law, University of Michigan. B.A. 1956, Amherst College; J.D. 1962, University of Michigan. Editorial Board, Vol. 60, Michigan Law Review.-Ed.

-* Member of the Michigan Bar. B.A. 1964, Kenyon College; J.D. 1968, University of Michigan.-Ed.

The authors wish to thank Mrs. Gay Vanderkolk, Professor White's secretary, and Richard A. Lenter, J.D. 1968, University of Michigan, who assisted in interviewing.

1. See, e.g., the landmark decisions in Williams v. Walker-Thomas Furniture Co., 350 F.2d 445 (D.C. Cir. 1964); Unico v. Owen, 50 N.J. 101, 232 A.2d 405 (1967). See also Ellsworth Dobbs, Inc. v. Johnson, 50 N.J. 528, 236 A.2d 843 (1967); American Home Improvement, Inc. v. MacIver, 105 N.H. 435, 201 A.2d 886 (1964); and cases cited in Annot., 17 A.L.R.3d 1010, 1136-38 (1968).

2. Consumer Credit Protection Act, May 29, 1968, Pub. L. No. 90-321, 82 Stat. 146, 15 U.S.C. \$§ 1601-77 (Supp. V, 1965-1969) [hereinafter CCPA].

3. UNIFORM CONSUMER CREDIT CODE (rev. final draft 1969) [hereinafter UCCC]. The UCCC has been adopted by Colorado, H. 1076, [1971] Colorado Laws (1 CCH CoNSUMER CREDIT GUIDE T 4770, at 5005 (1971)); Idaho, ch. 299, [1971] Idaho Laws (1 CCH Consumer Credit Guide I 4770, at 5005 (1971)); Indiana, INd. Code 1971, tit. 24, art. 4.5, \$\$1-101 to 6-202; Oklahoma, 14 OkLA. Stat. ANN., tit. 14A, §§ 1-101 to 9-103 (Supp. 1970); Utah, Utar Code ANN. §§ 70B-1-101 to -9-103 (Supp. 1969); and Wyoming, ch. 191, [1971] Wyoming Laws (1 CCH Consumer CREDIT GuIDE I 4770, at 5005 (1971)).

4. See, e.g., the Michigan Retail Installment Sales Act enacted in 1966, Mich. STAT. ANN. $\$ \$ 19.416(101)$ to (122) (Supp. 1971). Thirty-two states have installment sales acts covering most consumer goods (including motor vehicles), as compiled in scattered sections of the CCH CONSUMER CREDIT GUIDE under the respective state headings: Alaska, Calif., Colo., Conn., Del., Fla., Ga., Hawaii, Ill., Ind., Kan., Ky., Md., Mass., Mich., Mo., Mont., Neb., Nev., N.J., N.M., N.Y., N.D., Ohio, Okla., Ore., Pa., R.I., Texas, Utah, Vt., Wash. Thirteen states and the District of Columbia have acts covering only motor vehicles. See CCH CONSUMER CREDIT GUDE under the following headings: Ariz., D.C., Iowa, La., Me., Minn., Miss., N.H., N.C., S.C., S.D., Va., W. 
standing usury laws. ${ }^{5}$ These legislative and judicial acts have always relied, at best, on anecdotal knowledge of consumer behavior. In this Article we offer the results of an empirical study of a small slice of consumer behavior in the use of installment credit. ${ }^{\circ}$

Va., Wis. One state, Tennessee, has an installment sales act covering most consumer goods except motor vehicles. TENN. CODE ANN. \$\$ 47-11-101 to -110 (1964). See 3 CCH Consunier Credit GuIDE If 6001-19, at 50,611-15 (1970). Only four states have no installment sales act covering consumer goods: Ala., Ark., Idaho, Wyo. In addition, every state but Arkansas has enacted some form of legislation regulating small loans to consumers. E.g., Mich. Stat. ANN. $\$ \S 23.667(1)-(26)$ (1971). See chart in 1 CCH CONSTMER CREDTT Gume of 540, at 1603-35 (1970). And 41 states regulate installment loans to consumers under separate statutes. E.g., MICH. STAT. ANN. \$\$ 23.710(191)(c), (192), (196) (1971). See chart in I CCH CONSUMER CREDIT GUIDE II 570, at 1901-31 (1971).

5. Legislative concern for the consumer debtor is not entirely a modern development. Usury laws have been in effect for many years in virtually every jurisdiction. A good example is the Illinois law, enacted in 1879, Law of May 24, 1879, $\$$ 1-12, [1879] Ill. Laws 184-86, amended by Law of June 17, 1891, §§ 1-8, [1891] Ill. Laws 149-50, codified in ILL. ANN. STAT. ch. 74, \$\$ 1-11 (Smith-Hurd 1966). A typical usury law specifies a maximum rate of simple interest-or a maximum number of dollars per $\$ 100$ of principal that may be charged per annum-and a separate (usually higher) rate for loans under written contract. The older usury statutes usually do not define interest, and few specifically mention installment loan rates. Since these older usury statutes have operated to limit only "interest" rates and not other charges that were effectively interest on the money borrowed but were not termed interest charges in the loan agreement, the practice in making installment loans has been to assess "financing" or "carrying" charges in addition to "interest." See, e.g., Petersen v. Philco Fin. Corp., 91 Idaho 644, 428 P.2d 961 (1967); Sloan v. Sears, Roebuck \& Co., 228 Ark. 464, 308 S.W.2d 802 (1957). More recent installment sales acts and installment loan acts have been drafted specifically to include any type of charge, regardless of what it is called by the lender or seller, within the maximum rate and disclosure provisions of those acts. For example, the UCCC uses the term "credit service charge" instead of interest; the credit service charge is the sum of all direct and indirect charges incident to the extension of credit. UCCC $\S 2.109$.

6. Several empirical studies of consumer behavior in credit transactions already exist; economists have authored most of them. See A. BromA, ConsUMER SURVEYS AS A Source of Information for Social Accounting: The Problems (1962); G. Haberder, Consumer Installmment Cremit and Economic Fluctuations (1942); F. Juster, Household Capital formation and Financing, 1897-1962 (1966); F. Juster \& R. Shay, ConSUMER SENSITIVTIY TO FINANCE RATES: AN EMPIRICAL AND ANALYTICAL INVESTIGATION (1964); G. Katona, The Powerful Consumer (1960); A. KISselgoff, FActors AfFecting the Demand for Consumer Installment Sales Credit (1952); W. Mors, Consumer Credt Finance Charges: Rate Information and Quotation (1965); W. Mors, ConSUMER Credit Theories: A Historigal and Gritical ANalysis (1944); Opinion Research Corp., New Dimensions in Full Sertice Banking (1966); R. Shay, New Automobile FinaNce Rates 1942-62 (1963); UNIv. OF Michigan SURVEY REsearch CENTER, NovemaER 1959 INTERIM SURVEY (1959); Due, Consumer Knowledge of Installment Credit Charges, 20 J. MARKETING 162 (1955); Friedman, Using Simulation Techniques To Predict the Behavioral Effects of New Laws: The Case of Truth-In-Lending Legislation and the Consumer, 54 J. AppLIED Psych. 297 (1970); L. Hoskins, Interest Rates Paid for Auto. mobile Credit by San Francisco Bay Area Families, Sept. 1958 (unpublished M.A. thesis, Univ. of Calif.). To our knowledge, no one has examined the behavior of a group of borrowers in actual transactions. But see Friedman, supra. For a more thorough discussion of the several relevant empirical studies-which we will not review 
In their recent efforts, the legislatures, by imposing new interest rate disclosure requirements on installment lenders, ${ }^{7}$ have sought to protect the consumer against pressures to borrow money at a higher rate of interest than he can afford or need pay. The hope, if not the expectation, of the drafters of such disclosure legislation is that the consumer who is made aware of interest rates will seek

here-see W. Mors, Consumer Credit Finance Charges: Rate Information and QuoTATION (1965). In addition, economic literature contains a wealth of speculation about the use of information by consumers and an equal amount of empirical data that bears indirectly on the question whether finance rates are an important determinant in the use of credit. For example, A. KissercofF, supra, presents an analysis, using aggregate data for the United States, of the effects of such factors as loan rate, down payment, and loan term on the use of credit. His data were unsatisfactory to explain why consumers, or certain consumers, do not respond to particular variables. But he was able to show that, while changes in down-payment size and interest rates on newcar loans did not have a systematic effect on the aggregate purchases of new cars during the period he studied (1929-1941), the length of loan term did have such an effect. This finding is amply supported by more detailed survey data collected subsequently.

7. The disclosure provisions of the UCCC and the CCPA are virtually identical. In general, the creditor must disclose the dollar amounts to be charged a debtor, the credits for amounts already paid, a description or identification of the amounts, and the amounts charged in terms of a percentage of the principal. See UCCC $\$ \S 2.301-.313,3.301-.312$; CCPA $\S \S 121-29$, 15 U.S.C. \$\$ 1631-39 (Supp. V, 1965-1969). Both acts require that the percentage rate that is quoted to the consumer be calculated strictly in accordance with regulations adopted by the Federal Reserve Board. UCCC §§ 2.304, 3.304; CCPA \& 107, 15 U.S.C. \& 1606 (Supp. V, 1965-1969). The “percentage rate" is the equivalent simple annual interest rate computed according to one of several methods in common use by accountants prior to either act; the Federal Reserve Board has now published tables that can be used in stating this equivalent rate. See Bd. of Governors of the Federal Reserve System Reg. Z, 12 C.F.R. \& 226.5 (1970), and Annual Percentage Rate Tables for Truth-in-Lending Reg. Z (1969). The purpose in requiring a creditor or seller to state the charges on the loan in terms of simple annual interest is to allow a consumer to make intelligent comparisons between different creditors and alternate forms of financing that were not directly comparable prior to the acts unless one had a sophisticated knowledge of principles of accounting. The CCPA further requires use of certain terminology, size of lettering, and format in making the disclosure. CCPA \& 122, 15 U.S.C. \& 1632 (Supp. V, 1965-1969), and Reg. Z, 12 C.F.R. §§ 226.6(a), (j), 226.7(b)-(c), 226.8(c)-(d) (1970). The UCCC contains no such provisions.

The UCCC is also designed to remove existing barriers to competition among lenders; it is intended to replace a multiplicity of acts that now regulate different segments of the consumer loan market in most states. The repeal of prior acts would remove most licensing requirements for lenders now in the market, except those for banks and credit unions and similar institutions, and would allow new lenders to enter the loan and installment sales credit markets almost without restriction. The only constraint on entry contained in the UCCC is the requirement that persons engaged in the business of making loans to consumers at rates of interest higher than $18 \%$ be licensed. UCCC $\$ \$ 3.201,3.501-502$. Comments and discussion attending the drafting of these provisions make it clear that licensing is intended to be pro forma except in cases in which an applicant is likely to be unscrupulous or irresponsible. The clear intent of the drafters was to maximize competition through free entry into the market at every level. See Curran \& Fand, An Analysis of the Uniform Consumer Credit Code, 49 NEB. L. REv. 727, 728-35 (1970). 
the lowest-priced lender or will decide not to borrow. ${ }^{8}$ This migration of the consumers to the lowest-priced lender will, so the argument goes, require the higher-priced lender to reduce his rate in order to retain his business. ${ }^{9}$ These hopes and expectations are founded on the proposition that the consumer is largely ignorant of the interest rate that he pays; this ignorance presumably keeps him from going to a lender with cheaper rates. Knowledge of interest rates, it is believed, will rectify this defect and will make the consumer credit market much more nearly perfect.

Even on its face, the assumption that consumer debtors will make use of credit-cost information is open to serious question. ${ }^{10}$ The typical consumer often shops first for the good he wishes to buy and is psychologically sold on that good before he even considers the terms of his purchase agreement.11 Gurrent disclosure laws do not require sellers to advertise their rates; they require only that information be provided on the face of the loan contract. ${ }^{12}$ If the credit-cost information is not available until after the consumer has decided to buy, under what circumstances will the buyer use differences in interest rates to his advantage? If consumers using credit are largely insensitive to rate differences even when they are aware of those differences, disclosure legislation holds out a false hope. A

8. Johnson, Regulation of Finance Charges on Consumer Instalment Credit, 66 MICH. L. REv. 81 (1967); Shay, The Uniform Consumer Credit Code: An Economist's View, 54 CORNELI L. REv. 491 (1969).

9. CCPA § 102, 15 U.S.C. § 1601 (Supp. V, 1965-1969), states:

The Congress finds that economic stabilization would be enhanced and the competition among the various financial institutions and other firms engaged in the extension of consumer credit would be strengthened by the informed use of credit. The informed use of credit results from an awareness of the cost thereof by consumers. It is the purpose of this subchapter to assure a meaningful disclosure of credit terms so that the consumer will be able to compare more readily the various credit terms available to him and avoid the uninformed use of credit.

10. Professors Jordan and Warren acknowledge that some consumers undoubtedly use information about finance rates to their advantage but argue that there are situations in which such information will provide little or no help to consumers seeking credit. Jordan \& Warren, Disclosure of Finance Charges: A Rationale, 64 Mrch. L. REV. 1285, 1302-03, 1321 (1966).

11. A second case described by Professors Jordan and Warren is one in which an unsophisticated or uneducated consumer is not likely to take advantage of the information that is provided for his use because he does not understand the technical format of the information or does not understand how to use such information. Jordan \& Warren, supra note 10, at 1303, 1306-07. A third case they suggest is the "marginal" consumer, the consumer who must go heavily into debt in order to purchase items he considers necessary because he lacks liquid assets required for other types of financing and is therefore less likely to avoid bad bargaining because the amount saved by shopping for credit appears small beside the amount of his total outstanding debt. Id. at 1321.

12. See, e.g., UCCC §§ 2-302, 3-302; CCPA §§ 128(b), 129(b), 15 U.S.C. §§ 1638(b), 1639(b) (Supp. V, 1965-1969). 
principal purpose of the study on which this Article is based, therefore, was to test the hypothesis that consumers are insensitive to interest rates.

Presumably, consumers in a perfect market will behave like water in a pond, which gravitates to the lowest point-i.e., consumer borrowers should all turn to the lender that gives the cheapest loan. ${ }^{13}$ We began this project with a strong suspicion-based on the observations of others ${ }^{14}$ - that the consumer credit market is far from perfect and that water governed by the force of gravity is a poor metaphor with which to describe the behavior of consumer debtors. The consumer debtor's choice of creditor clearly involves consideration of many factors besides interest rate. Therefore, a metaphor that better describes our suspicions about the borrower's behavior in a market in which rate differences appear involves a group of monkeys in a cage with a new baboon of unknown temperament. The baboon squats in one corner of the cage near some choice, ripe bananas. In the far corner of the cage is a supply of wilted greens and spoiled bananas, the monkeys' usual fare. Some of the monkeys continue eating their usual fare because they are unaware of the new bananas and the visitor. Other monkeys observe the new bananas but do not approach them. Still others, more daring or intelligent than the rest, seek ways of snatching an occasional banana from the baboon's stock. The baboon strikes at all the brown monkeys but he permits black monkeys to eat without interference. Yet many of the black monkeys make no attempt to eat. One suspects that a social scientist who interviewed the members of the monkey tribe about their experience would find that many of those who saw and appreciated the choice bananas would be unable to articulate the reasons for their failure to eat any of them. The social scientist might also discover that a few who looked at the baboon in obvious fright would nevertheless deny that they were afraid. In addition, he might find that some were so busy picking fleas or nursing that they did not observe the choice bananas at all. We suspected that consumer borrowers had similarly diverse reasons for their behavior. We presumed that some paid high interest rates only because of

13. Such a hypothesis is discussed and modifications suggested by Jordan \& Warren, supra note 10, and Kripke, Gesture and Reality in Consumer Credit Reform, 44 N.Y.U. L. REv. I (1969). Modified versions of the perfect-market hypothesis, which proceeds on the assumption that the consumer knows and uses loan cost in selecting his creditor, are discussed and tested empirically in F. JUSTER \& $\mathbf{R}$. SHAY, supra note 6. 1303-04.

14. E.g., F. JUSTER \& R. SHAX, supra note 6; Jordan \& Warren, supra note 10, at 
ignorance of lower rates and that others correctly concluded that they could not qualify for a cheaper loan than they received. Others, we suspected, were merely too lazy or too fearful of bankers to seek lower rates.

To put the foregoing more precisely, our three major working hypotheses were the following:

(1) Many of those borrowing at high rates of interest could have procured the same loans in the same market at lower rates.

(2) Lack of knowledge that others offered loans at lower rates was among the least significant of the barriers to acquiring a loan at a lower rate.

(3) Debtors who sought loans at the lowest rate of interest may be distinguished as a group on the basis of social, educational, and economic indicators from those who did not seek lowcost loans.

To test these hypotheses, we examined a sample of persons who had obtained automobile loans in a money market in which there was significant competition among lenders.

\section{A Description of the Survey}

In the course of our survey, we interviewed a sample of persons residing in Washtenaw County, Michigan, who borrowed money to purchase new cars during the last 6 months of $1967 .^{15}$ We chose loans against automobiles partly because some data on the actual transactions were readily available in security agreements on file at the county register of deeds office. ${ }^{16}$ For the typical auto loan, the institution lending the money takes a security interest in the car and perfects that interest by filing a financing statement with the local register of deeds. The practice in Washtenaw County is for creditors to file a copy of the actual security agreement as a financing statement. The security agreement sets forth the terms of the contract: the down payment, the cash price, the time balance and finance charge, the cost of insurance, the size of the monthly payment, the loan terms, the rate of interest, and the car make and year. The

15. The questionnaire used is reprinted as Appendix $A$ to this Article.

16. Under Michigan law, a creditor must file a financing statement in the county of his debtor's residence in order to perfect a security interest in an automobile. Mrch. Stat. ANN. \$\$ 19.9302(3)-(4), 19.9401 (1964); Mrch. Star. ANn. \$ 9.1858(2) (1968). For a schedule of the information that we obtained from the security agreements, see Appendix B infra. 
security agreement also discloses whether the car dealer signed the loan contract. A second reason for choosing auto loans was that such loans are among the largest a consumer ever seeks: it is likely that auto loans involve the largest amounts-apart from a home mortgage loan-that a consumer undertakes to borrow in his lifetime. Hence, if the rate of interest were ever to make a difference to a consumer, it should be in this context, where a differential of one or two percentage points in an add-on rate can amount to several hundred dollars in interest cost. ${ }^{17}$ If the consumer will not seek the lowest interest rates on a $\$ 3,000$ loan, he is far less likely to shop for a low rate on a loan of $\$ 100$ or $\$ 200$. In addition to these reasons, some available empirical evidence suggests that persons borrowing large amounts of money-on the order of $\$ 1,000$ to $\$ 2,000$-remember the interest rate on their loans with greater accuracy than do those borrowing smaller amounts. ${ }^{18}$

Under Michigan law, the maximum interest rate that one may charge on an installment loan made to finance the purchase of a new car or a used car less than one year old is $\$ 6 / 100$ "add-on."10 The add-on charge may be computed with the following formula: Total charge $=H \times I \times Y$. In the formula, $H$ represents the number of hundreds of dollars of principal, I represents the dollars per $\$ 100$ interest, and $Y$ represents the number of years of the loan. To illustrate, assume there is a $\$ 6 / 100$ add-on charge on a $\$ 2,000$ loan repayable in 36 monthly installments. The total charge will be 20 (the number of hundreds of dollars of principal) times 6 (dollars per $\$ 100$ interest) times 3 (the number of years)-i.e., $20 \times 6 \times 3=\$ 360$. The total of $\$ 2,360$ is then divided by 36 (the number of months in 3 years) to derive the debtor's monthly installment payment of $\$ 65.56$. Here the $\$ 6 / 100$ add-on interest is equivalent to an effective simple annual interest rate of about $11.25 \% .^{20}$

17. A new-car buyer seeking a $\$ 3,000$ loan will pay $6 \%$ of $\$ 3,000$, or $\$ 180$ a year, for the lifetime of the loan if he borrows at the rate of $\$ 6 / 100$ add-on. (For a complete explanation of the meaning of "add-on," see text accompanying notes $19 \& 20$ infra.) A new-car buyer with a $\$ 3,000$ loan paying a rate of $\$ 4.50 / 100$ add-on will pay $4.5 \%$ of $\$ 3,000$, or $\$ 135$ per year. Most new-car loans are made for a period of 3 years; thus the difference between the two rates means a difference in interest cost of $\$ 185(3 \times \$ 45)$ over the lifetime of the loan.

18. F. JUSTER \& R. SHAY, supra note 6 , at 33-40. Juster and Shay found that in a sample of 16,000 Consumer's Union members, accurate recall of interest rates increased with the size of the loan.

19. MICH. StAT. ANN. \$ 23.628(18) (1971).

20. Several methods of converting add-on rates to simple annual interest rates were in common use prior to passage of the CCPA. The CCPA and the UCCC adopted a uniform rule, known as the "actuarial" method, for conversion to simple 
During 1967, most of the lenders in Washtenaw County loaned money for new cars at $\$ 6 / 100$ add-on. Two of the largest lenders were of particular interest: Ann Arbor Bank (AAB), the largest bank in the county and the holder of the most automobile paper of any bank in the county, ${ }^{21}$ and General Motors Acceptance Corporation (GMAC), the financing subsidiary of General Motors. We were interested in GMAC because we were told that it would take greater risks and lend to less solid debtors than would the banks. ${ }^{22}$ Both of these lenders reputedly loaned to most new-car buyers at $\$ 6 / 100$ addon. Also lending money in Washtenaw County was a smaller bank, Huron Valley National Bank (HVNB), which loaned money at $\$ 4.50$ / 100 in 1967 (8.5\% simple interest on a 3-year loan). This bank, the newest in Ann Arbor, started its operations in 1963 and was conducting a vigorous advertising campaign in 1967 in an effort to attract automobile loan customers. An illustration of the type of advertising used by HVNB is attached as Appendix C.

GMAC purchased its paper from dealers or received it through dealer referrals, and $\mathrm{AAB}$ acquired most of its paper in the same way; but HVNB wrote almost all of its own paper in the form of direct loans. Because it loaned directly to the consumer, HVNB avoided one usual lender's cost-the finder fee or kickback commonly paid to dealers who sell paper. ${ }^{23}$ We assumed that both banks and GMAC were part of the market in auto loans because all did business in Ann Arbor, the largest city in the county; nearly all of the residents of the county live within a few minutes' drive of Ann Arbor. HVNB has branches only in Ann Arbor; $\mathrm{AAB}$ has branches in Ann Arbor and in one other city 8 miles away; and GMAG makes loans through all General Motors dealers.

Using the Washtenaw County Register of Deeds records of financing statements filed in the last 6 months of 1967, we drew samples

annual interest. The equivalent simple annual interest rates given in the text are taken from the Annual Percentage Rate Tables published by the Federal Reserve Board (see note 7 supra) and are those which would be required under the two acts. See W. Mors, Consumer Credit Finance Charges: Rate Information and Quotation (1965); W. Willier \& F. Hart, Consuner Credrr Handbook 163 (1969).

21. All the bank loan officers with whom we talked believed that Ann Arbor Bank [hereinafter AAB] held the most automobile paper. We know of no public records that confirm or refute their judgment.

22. Before beginning our survey, we talked with loan officers at several banks in Ann Arbor to find out about local interest rates and kickbacks, as well as their views of the market.

23. For a brief discussion of dealer-bank financing arrangements, see White, Representing the Low Income Consumer in Repossession, Resales and Deficiency Judgment Cases, 64 Nw. U. L. REv. 808, 834 \& n.92 (1970). 
for each of the 3 lenders. ${ }^{24}$ Personal interviews were conducted during 1968, and most were completed by the end of that summer. Altogether we interviewed 235 respondents, with a response rate of $66 \% .{ }^{25}$ Twenty-two per cent of the sample was never contacted by an interviewer, and $12 \%$ refused to be interviewed. Our respondents constitute a "stratified" sample, not statistically representative of all persons borrowing to buy new cars in 1967 in the county, but representative of the buyers borrowing through $H V N B, A A B$, and GMAC. Constructing the sample in this way allowed us to make statistically valid comparisons between selected banks that, we thought, were likely to lend to different types of customers. We think the sample, taken as a whole, is also a fair cross-section of the newcar buyers in the county, and we believe it can be used for descriptive purposes as if it were representative.

24. The sampling procedure was complex and a trifle sloppy. The register of deeds places financing statements in sequentially numbered files in the order of filing. By going through the files for the last 6 months of 1967, we obtained lists of 1018 debtors of AAB, 746 debtors of General Motors Acceptance Corporation [hereinafter GMAC], and 381 debtors of Huron Valley National Bank [hereinafter HVNB]. The samples drawn from these lists (1/6 samples from the AAB and GMAC lists and a 1/3 sample from the HVNB list) did not make allowance for "trash"-financing statements that covered security interests in merchandise other than new cars. After the trash was removed, we drew a second sample from each of the lists so that the total number of new-car buyers borrowing from each of the 3 creditors approximated the desired sizes. The final sample from AAB numbered 134; that from GMAC, 117; that from HVNB, 109. Theoretically, the second samples drawn from each of the lists violate the rule of equiprobability sampling because each of these respondents had a slightly greater chance of being included in the final combined sample. Although our procedure does not conform to the most desirable survey-sampling practice, it is unlikely that the error has rendered the sample unrepresentative in any way.

25. The response rate is calculated by dividing the number of respondents who consented to be interviewed by the total number of borrowers in our sample (after we excluded any nonsample respondents). Nonsample respondents are persons who, contrary to the information available from the financing statement, in fact were not financing through one of the banks in which we were interested or who were not financing new cars. Two respondents who refused to complete an interview that had been begun are counted as having been interviewed for the purposes of calculating the response rate.

Final Status of SURVEX SAMple

\begin{tabular}{lccrr}
\hline & GMAC & AAB & \multicolumn{1}{c}{ HVNB } & \multicolumn{1}{c}{ Total } \\
\hline Interviews & $69(59.0 \%)$ & $103(77.0 \%)$ & $64(59.0 \%)$ & $236(65.5 \%)$ \\
Refusals & $28(19.7 \%)$ & $10(7.4 \%)$ & $11(10.1 \%)$ & $44(12.2 \%)$ \\
Never Contacted & $25(21.4 \%)$ & $21(16.0 \%)$ & $34(31.2 \%)$ & $80(22.2 \%)$ \\
\hline Total* & $117(100.1 \%)$ & $134(100.4 \%)$ & $109(100.3 \%)$ & $360(99.9 \%)$ \\
\hline
\end{tabular}

- Because percentage figures have been rounded off, the printed figures do not necessarily total $100.0 \%$. 


\section{MOST REspondents Who BorRowed AT THE Maximum Legal Rate Could Have Borrowed AT A LOWER RATE}

If the new-car loan market in Washtenaw County were a perfect market in which lenders were distributed by reference to a single variable-money cost-then one would expect the high-priced lenders to serve the high-risk debtors and the low-priced lenders to serve the low-risk debtors. In 1967 there was significant rate competition in the new-car loan market. HVNB made all but an insignificant number of its loans at $\$ 4.50 / 100$, while GMAG and AAB made all but a small number of their loans at $\$ 6 / 100$, a rate $1 / 3$ higher than HVNB's rate. The magnitude of this rate difference is illustrated by the corresponding $\$ 135$ difference in the cost of a $\$ 3,000$ loan over 3 years. ${ }^{26}$

To test the hypothesis that many borrowers who were low risks and would have qualified for the $\$ 4.50 / 100$ rate had in fact borrowed at the $\$ 6 / 100$ rate, we asked the HVNB loan officer who actually made the final decision on HVNB loans in 1967 to pass on 48 hypothetical loan applicants. ${ }^{27}$ Among these 48 were the cases of 38 persons whom we had interviewed and who had in fact borrowed from $\mathrm{AAB}$ (18 cases) or from GMAG (20 cases) in 1967. Six were persons who had actually borrowed from HVNB in 1967 and 4 were fictitious cases.

In each of the AAB- or GMAC-borrower cases presented to the HVNB loan officer, we knew, on the basis of the interview or the security agreement that had been filed, the debtor's income, job history, general financial status, the kind of car that he had purchased in 1967, and the terms of the loan that he had procured at that time. We could not present the debtor in the flesh for a personal interview with the loan officer, nor could we provide a reference from a current creditor of the debtor. ${ }^{28}$ However, we were able to give the loan officer all the other data that he would normally use to decide

26. See note 17 supra.

27. Out of consideration for the loan officer's schedule, we set an arbitrary maximum of 50 on the number of cases presented to him. We first selected every tenth AAB interview (in order of completion) and every fifth GMAC interview. That process produced 10 of each, or samples of about $10 \%$ and $15 \%$, respectively. After making a decision to double this number, we selected every tenth-plus-one $A \mathrm{AB}$ interview and every fifth-plus-one GMAC interview. The procedure was, for our purposes, satisfactory to give us a representative subsample of interviews from the 2 banks.

28. A "routine check" of credit references at HVNB meant telephoning 1 or 2 current or recent creditors (preferably creditors from the immediate area) to obtain information about the loan applicant's payment history. 
whether to loan and on what terms to make a loan. ${ }^{29}$ It will come as no surprise that the debtor's disposable income and his job stability were the two most important considerations for the loan officer. ${ }^{30}$ Other relevant factors he normally considers were as diverse as whether the debtor had had a recent divorce, ${ }^{31}$ his general appearance, ${ }^{32}$ his education, and the type of car that he wished to purchase. ${ }^{33}$

29. The terms of each debtor's actual loan were available to us from the security agreements that the creditor filed with the register of deeds and from which we initially obtained the respondent's name. For each hypothetical case, the HVNB loan officer indicated the amount and type of loan that he would have made in 1967 to the persons we described. To the best of his ability under the circumstances, he also indicated what factors were important in making each decision. Since the loan officer had no opportunity to interview any debtor and since he had to put himself in the frame of mind that he had in 1967 in a different credit market, his judgment about what he would have done in 1967 is probably not entirely accurate. Furthermore, he stipulated that he was proceeding on the assumption that the debtor could produce credit references to verify some of the information. Despite these difficulties, the loan officer believed he was able to approximate closely what he would have done with each of the loan applications in 1967.

30. The factors that influence the loan-making decisions of $A A B$ and GMAC are probably the same as those that influence HVNB. Both AAB and GMAC do a highvolume business in car loans and lend on the basis of information telephoned to them by dealers-nearly all of GMAC's and more than 8/4 of AAB's new-car loan business is conducted in this manner. On the other hand, HVNB considers itself a more cautious, low-volume lender in the new-car loan market and interviews all of its potential debtors. Nevertheless, differences, if any, in the types of customers to whom the 2 banks and GMAC lend are almost certainly the result of the lenders' respective decisions to take more or fewer risks rather than the result of different weights attributed to particular characteristics of buyers.

31. A recent divorce indicates the possibility of liability for alimony or child-support payments or of more general financial difficulty, from which, in the opinion of the loan officer, divorces frequently stem.

32. In the course of drafting this section, the following exchange of footnotes took place:

(White's proposed footnote) When the loan officer described neat personal appearance as a desirable debtor attribute, one of your authors, whose appearance that day could most charitably be described as slovenly, went into an uncontrollable fit of petting and grooming his mane.

(Munger's substitution) Your other author is a member of the Air National

Guard and under its vigilant eye has never let more than a quarter-inch of hair show at one time. We understand his caution has been rewarded by several favorable loansl

In any event, while the potential impact of appearance and other such subtle factors on chances for obtaining a loan seem important, we were unable to measure them adequately. Our conclusions therefore should be considered in light of the effect such factors could have on an actual loan application. See note 69 infra.

33. The loan officer expressed the following reasons for considering the type of car a borrower wanted to purchase. The typical car buyer should be looking for a car that fits his budget and that will be serviceable for some time. The more practical the choice of car appears to be, the more certain the loan officer can be of the person's potential reliability in making future payments. Conversely, a car that is flashy, faddish, or generally too large for the customer's budget may indicate temporary enthusiasm, may foretell future loss of interest in paying for a status symbol, and may warn that the buyer will default shortly before leaving town. The loan officer said that when making loans for luxury cars or for sports cars, he often required as 
Each of these last-mentioned factors took a back seat in the loan officer's mind to income, job security, and at least one credit reference.

Having put himself in his 1967 frame of mind, the HVNB loan officer gave us his best estimate of the maximum amount he would have loaned in 1967 to each of our 48 potential borrowers. A most interesting finding is that he would have loaned money to 36 of the 38 persons who procured loans at GMAC and AAB; he found only 2 of them to be totally unworthy of credit (see Table 1). Of course, the fact that he would have loaned some money to each of the other 36 does not mean that each of them could have procured a satisfactory loan from HVNB, for in some cases he would have required a much higher down payment than that required by the higher-priced lenders; it is probable that some of these borrowers did not have the resources to come up with additional down-payment money. However, as Table 1 discloses, HVNB would have made at least the same loan as the higher-priced lenders made or would have required less than $\$ 100$ additional down payment in $45 \%$ of the GMAC cases and in $39 \%$ of the $\mathrm{AAB}$ cases. ${ }^{34}$ These results indicate that if all or nearly all of them could have come up with an additional $\$ 100$ down payment, more than $42 \%$ of the $\mathrm{AAB}$ and GMAC customers could have procured a nearly identical loan at HVNB at a rate $1 / 4$ lower than the one they were paying. If GMAC and $\mathrm{AAB}$ borrowers could have come up with an additional $\$ 250$ down payment, then more than $60 \%$ of them could have qualified for a $\$ 4.50 / 100$ loan at HVNB.

Whether the HVNB loan officer in fact would have made the loans on the terms that he described, we have no way of know-

much as $1 / 3$ of the price down, whereas the normal minimum down payment was about $20 \%$ of the price. Apparently because of such caution there had been only 6 to 8 repossessions on 6000 outstanding loans during the 6 months preceding the interview.

34. In the remainder of this Article, we concern ourselves primarily with trying to explain why persons who could have borrowed at HVNB did not do so. We assume that a person first decides what kind of car he wants and then looks for a loan. Someone wishing to purchase an expensive car in 1967 on a moderate or small income was required to pay a large down payment in order to obtain a loan through FVNB (see note 33 supra). We were told by some respondents and by bank loan officers with whom we spoke before conducting our survey that GMAC offered "easy credit," that is, that GMAC accepted low down payments on expensive cars even if the borrower's income was moderate. If this is true, a borrower buying a large car on a small income and wishing to make a normal or small down payment is effectively limited in the number of lenders to which he may turn. Our data show that more than $50 \%$ of the cars financed by GMAG in Washtenaw County in 1967 cost over $\$ 3,000$ and that fewer than $50 \%$ of the cars financed by AAB and HVNB cost $\$ 3,000$ or more. In addi- 


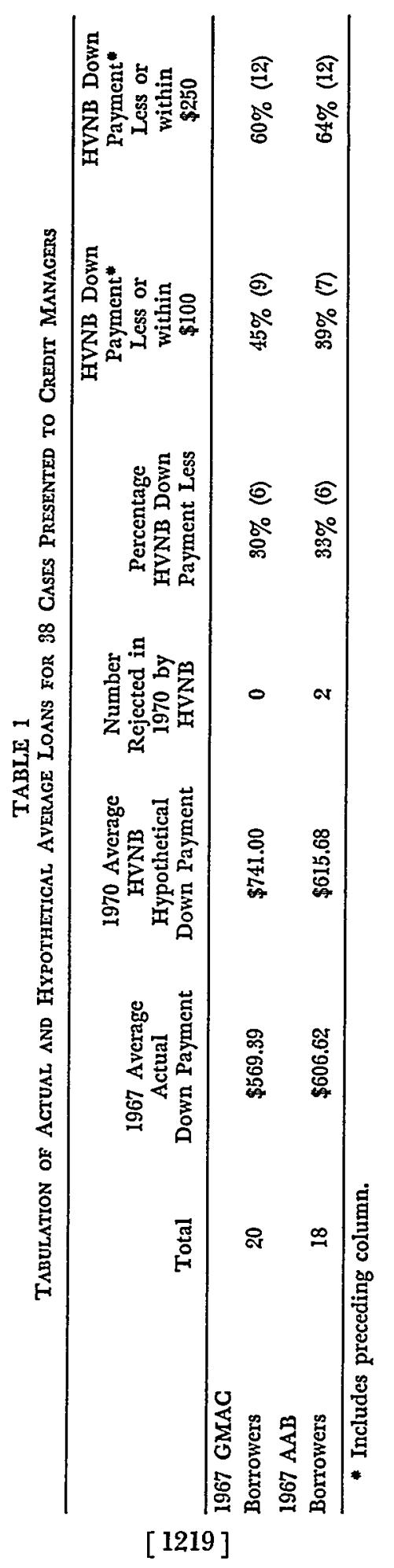


ing. ${ }^{35}$ The debtors might have been a wholly unpersuasive lot, who lacked reliable credit references. On the other hand, they might have persuaded him to lend even more money than he told us he would have loaned. Most important, our data show that the AAB and GMAC borrowers had no greater liabilities and no less income

tion, the average difference between the down payments actually made by GMAC borrowers and those that HVNB would have required in 1967 on cars priced over $\$ 3,000$ was substantially greater than the average difference between AAB down payments and those that HVNB would have required in 1967.

Comparison of Down Payments Made to GMAC and AAB on Gars Priced $\$ 3000$ or More WTTH HVNB Hypothetical Down Payments

\begin{tabular}{lcccc}
\hline & $\begin{array}{c}\text { Average } \\
\text { Actual } \\
\text { Down Payment }\end{array}$ & $\begin{array}{c}\text { Average HVNB } \\
\text { Hypothetical } \\
\text { Down Payment }\end{array}$ & $\begin{array}{c}\text { No. of Loans on } \\
\text { Which HVNB Down } \\
\text { Payment Smaller }\end{array}$ & N \\
\hline GMAC & $\$ 456.16$ & $\$ 849.50$ & 1 & 12 \\
$\begin{array}{l}\text { Borrowers } \\
\text { BAB }\end{array}$ & $\$ 885.25$ & $\$ 1028.25$ & 2 & 4 \\
\hline
\end{tabular}

Similarly, among all our respondents the average down payment made by HVNB borrowers on all new cars was $29.7 \%$ of the purchase price, the average down payment to AAB was $22.0 \%$ of the purchase price, and the average down payment to GMAC was $18.0 \%$ of the purchase price (see Item $5 \mathrm{~b}$ in Appendix B). Finally, a disproportionate number of lower-income GMAC borrowers in our sample (under $\$ 10,000$ total family income) were financing cars priced at $\$ 3,000$ or more. Fourteen of the 18 GMAC borrowers-about 78\%-with incomes under $\$ 10,000$ bought cars priced over $\$ 3,000$. Thirty per cent of the 47 low-income AAB borrowers bought cars costing at least $\$ 3,000$. And $42 \%$ of the 29 low-income HVNB borrowers bought cars priced at $\$ 3,000$ or more.

What we conclude from these figures is that new-car buyers with smaller incomes who have decided to buy an expensive car gravitate to a lender with a reputation for easy credit. (When asked why they borrowed from GMAC, several of our respondents gave precisely this reason; see Questions III B-2 and IV B in Appendix A.) Many of these probably would have been refused the same loan at HVNB. Moreover, a buyer who is willing go deep into debt for the sake of a grossly uneconomical purchase may also be quite willing to take the most convenient loan rather than worry about a few extra dollars interest.

35. As a check on the accuracy of the HVNB loan offcer's judgment and on the importance of the information that we were not able to give him, we included 6 borrowers from our sample who had borrowed from HVNB through this loan officer in 1967 and compared his 1970 decisions with the terms of the actual 1967 loans. As an additional check, we included 4 fictitious and exceptionally risky cases to help us judge whether or not the loan officer unrealistically lowered the bank's standards.

The results of these checking procedures show that the minimum down payment the loan officer would require in 1970 on the basis of the information we gave him was somewhat lower than that actually paid by 4 out of the 6 persons who had actually borrowed from HVNB in 1967. The following table summarizes the data on which we base our assessment of the accuracy of the HVNB loan officer's estimates.

(Footnote continued on next page) 
or assets than did the HVNB borrowers. ${ }^{36}$ Apart from the fact that each of the 38 borrowers in our hypothetical sample who dealt with

Comparison of loans Actually Made by HVNB and Maximum Loans OfFEred by HVNB LOAN Officer Three YeArs LATER

\begin{tabular}{lcccc}
\hline Price & $\begin{array}{c}\text { Actual } \\
\text { Time Balance }\end{array}$ & $\begin{array}{c}\text { Hown Payment } \\
\text { (\% of Price) }\end{array}$ & $\begin{array}{c}\text { Hypothetical } \\
\text { Maximum } \\
\text { Loan }\end{array}$ & $\begin{array}{c}\text { Hypothetical } \\
\text { Minimum } \\
\text { Down Payment } \\
\text { (\% of Price) }\end{array}$ \\
\hline$\$ 3000$ & $\$ 2287$ & $\$ 900(30.0 \%)$ & $\$ 2481$ & $\$ 700(23.4 \%)$ \\
$\$ 200$ & 2017 & $1450(45.1 \%)$ & 2725 & $700(21.8 \%)$ \\
2990 & 1767 & $1457(48.6 \%)$ & 2837 & $490(16.4 \%)$ \\
2859 & 2959 & $294(10.3 \%)$ & 2497 & $659(22.1 \%)$ \\
2500 & 2193 & $1181(47.3 \%)$ & 2837 & $581(23.1 \%)$ \\
4387 & 4284 & $487(11.1 \%)$ & 3488 & $1187(27.1 \%)$ \\
\hline Average & $\$ 2584.5$ & $(32.1 \%)$ & $\$ 2811$ & $(22.3 \%)$ \\
Average & $(29.7 \%)$ & & \\
\hline
\end{tabular}

The loan officer would not accept any of the fictitious borrowers-who were all very bad risks. One of the 2 loans that he made in 1967 but said he would not make for the same amount when we presented him with the same information in 1970 was a loan to a self-employed businessman for an expensive car. The loan officer said that this is one of the "problem" situations that he handles very cautiously. Had he known that the individual had a reputation for sound credit or had he checked credit references, he probably would have been willing to offer this individual as much as he did in 1967. Our inability to provide the loan officer with credit references and with the identity of the borrower, a local merchant, changed the outcome. Furthermore, the loan officer's tendency in 1970 to offer smaller down payments than were actually required in 1967 is consistent with the fact that borrowers frequently wish to borrow less than the maximum the bank is willing to lend and that we had asked the officer to estimate the maximum amount he would lend. In any event, only in exceptional cases was the loan officer willing to allow a borrower to put down less than $20-25 \%$ of the price-a percentage that the loan officer said the bank requires for low- and middle-priced cars-or $30 \%$ of the price-the amount the bank regularly requires for high-priced cars. Although we could check his accuracy only very generally, we conclude that the loan officer's standards were not unrealistically low; despite the absence of information -e.g., credit references-he gave us a reasonably accurate picture of what the bank would have been willing to lend had the real borrowers asked for loans in 1967.

36. INCOME OF RESPONDENTS

(In Thousands of Dollars)

\begin{tabular}{lcccccccc}
\hline & $0-5$ & $5-7.5$ & $7.5-10$ & $10-12.5$ & $12.5-20$ & $20+$ & Total* & N \\
\hline GMAC & $4.8 \%$ & $4.8 \%$ & $19.0 \%$ & $27.0 \%$ & $41.4 \%$ & $3.2 \%$ & $100.2 \%$ & 63 \\
AAB & $5.2 \%$ & $18.7 \%$ & $22.8 \%$ & $23.9 \%$ & $18.7 \%$ & $10.4 \%$ & $97.7 \%$ & 96 \\
HVNB & $4.9 \%$ & $11.5 \%$ & $31.2 \%$ & $13.1 \%$ & $23.0 \%$ & $16.4 \%$ & $100.1 \%$ & 61 \\
& \multicolumn{7}{c}{ Median for GMAC, AAB, HVNB, and Total $=\$ 10-12,500$} & \\
\end{tabular}

- Because percentage figures have been rounded off, printed figures do not necessarily total $100.0 \%$.

It should be noted that our sample does not include consumers with marginal incomes. By selecting only new-car loans we have doubtless excluded the ghetto dweller and the abject poor. 
$\mathrm{AAB}$ or GMAC agreed to pay the maximum rate possible, we know nothing about them that suggests that they represented greater risks or that they were for any other reason less attractive borrowers.

Some may argue that we dwell too long on an obvious truthnamely, that the consumer market is horribly imperfect. We reject that argument. We believe it significant that a large minority and perhaps a majority of those who borrowed from the most expensive and least conservative creditor in the market could have had the same or nearly the same loan with the most conservative and least expensive creditor. Is it not remarkable that a majority of the newcar buyers may have been paying $25 \%$ more interest than they had to pay? Certainly the bank loan officers most familiar with the market, with whom we spoke before we conducted the survey, painted a picture of the market-one in which high-risk customers were concentrated at GMAC and similar institutions-quite different from the one that we discovered. We also suspect that some of the proponents of disclosure legislation would not have thought the market to be as insensitive to price differences as it proved to be. An equally intriguing and more elusive question to which we now turn is why those apparently able to borrow at a significantly lower rate failed to do so.

\section{Lack of KNowledge That Others Offer a Lower Rate Was Not the Principal Deterrent for Most Persons Who Falled To Borrow at the Lower Rate}

A variety of facts suggests that the rate of interest charged on his loan is not an important fact in the eyes of the typical automobile buyer. First, our data confirm findings made elsewhere that consumers are ignorant of rates (see Table 2). ${ }^{37}$ A majority of our sample-an overwhelming majority if one excludes the respondents who borrowed at HVNB-were ignorant of the interest rate that they were paying on their auto loans. When one combines this ignorance of rates with the fact that all of the persons interviewed had contracted for their loans within the year previous to the interview and were still making payments on those loans, he is at least nudged toward the conclusion that the interest rate was not uppermost in the borrowers' minds at the time the loans were arranged.

37. See, e.g., F. JUSTER \& R. SHAX, supra note 6; Due, supra note 6; Hoskins, supra note 6. 
TABLE 2

\begin{tabular}{lcccc}
\hline & $\begin{array}{c}\text { Knew Exact } \\
\text { Add-On Rate }\end{array}$ & $\begin{array}{c}\text { "Knew Add-On } \\
\text { Rate within } \\
5 \%\end{array}$ & $\begin{array}{c}\text { Did Not Know } \\
\text { Add-On Rate } \\
\text { within } 5 \%\end{array}$ & \\
\hline HVNB & $51.0 \%$ & $63.5 \%$ & $36.5 \%$ & $100.0 \%(63)$ \\
AAB & $20.4 \%$ & $34.8 \%$ & $65.2 \%$ & $100.0 \%(103)$ \\
GMAC & $28.0 \%$ & $45.5 \%$ & $54.5 \%$ & $100.0 \% \quad(68)$ \\
\hline Total $†$ & $27.8 \%$ & $43.1 \%$ & $56.9 \%$ & $100.0 \%(202)$ \\
\hline
\end{tabular}

- Includes Column A.

$\dagger$ Weighted by Lender (see note 24).

A second fact consistent with the hypothesis that interest rate is comparatively unimportant to the credit buyer is the willingness of most respondents to allow the automobile dealer to arrange the loan rather than to shop for the lowest available rate. Altogether $65.5 \%$ of our respondents and approximately $75.5 \%$ of all the borrowers at GMAG, AAB, and HVNB allowed the dealer to arrange the loan..$^{38}$ While our sample is statistically representative of the borrowers of only 3 lenders in the county, the fact that most other large lenders in the area made loans through dealers at $\$ 6 / 100$ add-on in 1967 leads us to the conclusion that at least $75.5 \%$ of all the newcar loans in the Washtenaw County market are made through the dealer at or near the maximum rate permissible by law. ${ }^{30}$

Among our respondents who allowed the dealer to arrange the loan, only $11 \%$ (14) made any prior inquiry elsewhere about loans. If the dealer at the point of contracting had said that the loan would be made at $\$ 7 / 100$ or even $\$ 8 / 100$, is it plausible that these people would have gone elsewhere to borrow? There is certainly no evidence from our respondents to indicate that they would have done so.

Also militating in favor of discounting interest rate as an important factor-at least among those who accepted the loan offered by the lender-are the reasons given by respondents for allowing the

38. The reason for the difference between the 2 figures is the double proportion of HVNB borrowers in our sample (see note 24 supra). The $75.5 \%$ figure is corrected to represent the true proportion of the borrowers of the 3 lenders.

39. The loan officer at $\mathrm{AAB}$ stated that every car dealer in the county had some form of referral arrangement with at least $I$ lender. $\mathrm{He}$ and the HVNB officials agreed that HVNB was one of the few exceptions to the general rule of "indirect" lending. A letter that a local auto-dealers association sent to HVNB's president shortly after that bank opened discloses how exceptional the HVNB policy is. That letter characterized HVNB's direct-loan policy as shortsighted; it offered HVNB "membership" in the local combination in restraint of trade and forecast economic disaster for a bank that did not buy paper from dealers. 
dealer to arrange the loan (see Figure 1). The largest number of respondents said that they agreed to the loan arranged by the dealer because they had had previous experience with the creditor, $A A B$ or GMAC. The second most frequent response was that of "convenience." Well down the list of reasons was low cost. Conceivably, some of those people would have gone elsewhere had they known they were not getting a cheap loan; but we are skeptical. The propensity to deal again with a familiar creditor and the emphasis on the convenience of allowing the dealer to arrange the loan may be taken at face value as an indication of laziness or lack of interest in competing offers or as a sign of debtor insecurity about dealing with unfamiliar creditors.

Fourth, there is an understandably high coincidence between the place where a borrower lived and the place where he borrowed (see Table 3). All 3 creditors have branches or dealer representatives in the city of Ann Arbor. HVNB, however, has branches only in Ann Arbor, and AAB has only 1 branch outside Ann Arbor. GMAG, on the other hand, makes loans through all General Motors dealers in the county. Ypsilanti, the second largest city in the county, is located about 4 miles from Ann Arbor (in the opposite direction from AAB's out-county branch) and does not have branch offices of either bank we studied. Over $80 \%$ of HVNB's borrowers lived in Ann Arbor, the location of all of its branches. Nearly the same percentage of

TABLE 3

$(\mathrm{N}=235)$

REsPondents' Place of Residence

\begin{tabular}{lccccr}
\hline & Ann Arbor & Ypsilanti & Dexter & Other & Total* \\
\hline HVNB & $81.3 \%$ & $4.7 \%$ & $1.6 \%$ & $12.5 \%$ & $100.1 \%$ \\
AAB & $66.0 \%$ & $8.7 \%$ & $12.6 \%$ & $11.7 \%$ & $99.0 \%$ \\
GMAC & $25.0 \%$ & $47.1 \%$ & $1.5 \%$ & $26.4 \%$ & $100.0 \%$ \\
\hline
\end{tabular}

* Because percentage figures have been rounded off, the printed figures do not necessarily total $100.0 \%$.

AAB's customers lived in Ann Arbor and Dexter, the cities in which all of AAB's branches are located. In contrast, approximately $75 \%$ of GMAC's business came from outside Ann Arbor or Dexter. The conclusion one draws from these data, of course, is that geographical location and the convenience associated with geographical proximity is an important factor in a borrower's decision about where to borrow.

A final piece of evidence-indeed, the only direct evidence-that supports the conclusion that lack of knowledge was not the principal 
FIGURE I

Reasons Given for Borrowing Through an Auto Dester*

$\prod_{N=64}^{A A B} \stackrel{\text { GMAC }}{\therefore:} \prod_{N=66}^{\text {Average }}$

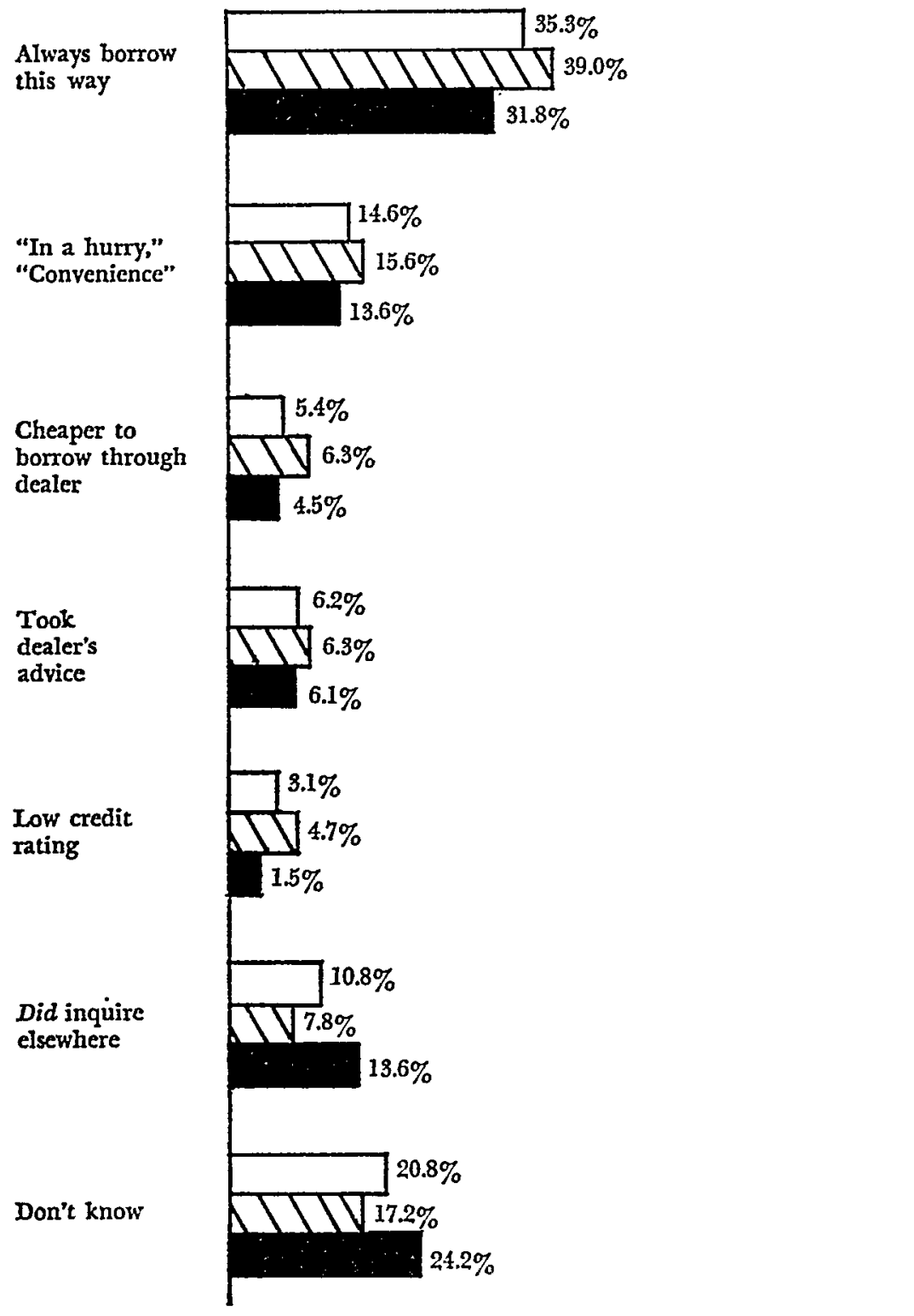

- HVNB is not included because only 2 of our 64 HVNB respondents had dealermade loans. Approximately $97 \%$ of all GMAC loans and about $62 \%$ of all AAB loans were arranged through the dealer. 
deterrent to comparative shopping by debtors is our finding that approximately $29 \%$ of GMAC and $A A B$ respondents knew of at least 1 lender in the county that loaned at a rate lower than the one they were paying. Some of these persons mentioned institutions from which they could not have borrowed-for example, the University of Michigan Employees' Credit Union-but most of them named lending institutions that loaned money to the general public. As our discussion in part $V$ will show, this group of people who had the knowledge but did not use it is by no means a group of unusually bad credit risks; nor were these debtors prevented from taking advantage of the lower rate by any financial disadvantage that we could discover.

We asked the $29 \%$ who knew about a lower rate of interest but did not take advantage of it this question: "Why didn't you borrow from the creditor offering the lower rate?" Their answers were consistent with the theory that interest rate is outweighed by other considerations in the minds of those buyers who know a lower rate and can weigh that knowledge against other factors (Figure 2). Some of these respondents were like the monkeys:40 they admitted fear of dealing with the new creditor who might have rejected them or required anxiety-producing credit-checking procedures. By way of justification, they emphasized strength of established ties to a familiar or more convenient creditor.

We are particularly suspicious of the "convenience" responses, the largest single category (44\%).11 We suspect that some, and perhaps many, of the respondents used "convenience" as a euphemism for "The dealer is friendly, but I'm threatened by those stuffy bankers." Others may have used "convenience" as a graceful admission of surrender to dealer pressure. ${ }^{42}$

40. See text following note 13 supra.

41. Not only in our study but also in others, "convenience" responses predominate among explanations given by borrowers for using installment credit offered by the seller instead of bank credit. See OpINION RESEARCH CoRP., supra note 6.

42. For the report of an undercover agent who sold cars for a short time, which describes the unscrupulous but effective pressures that a car dealer may apply to nail down a deal, see Rapoport, How I Made \$193.85 Selling Cars, ATLANtic Montrisy, Jan. 1970, at 75. See also Shannon, The Baffing Facts About Shopping for a New Model Gar in Detroit, Detroit Free Press, Jan. 25, 1970, \& B, at 1, col. 1 .

Others have interpreted the "convenience" response and other data to mean that competition lies in areas other than interest rate. They also conclude that the market tends to divide on the basis of risks that creditors are willing to take instead of on the basis of rates. See Harper, The Uniform Consumer Credit Code: A Critical Analysis, 44 N.Y.U. L. REv. 53, 67-68 (1969). Our own data tend to confirm this interpretation of convenience responses, but our data do not show that there are significant 
FIGURE 2

REASONS WHY THOSE WHO KNEW OF A LOWER-COST LENDER DID NOT SEEK A LOWER-COST LOAN

$(\mathrm{N}=59)$

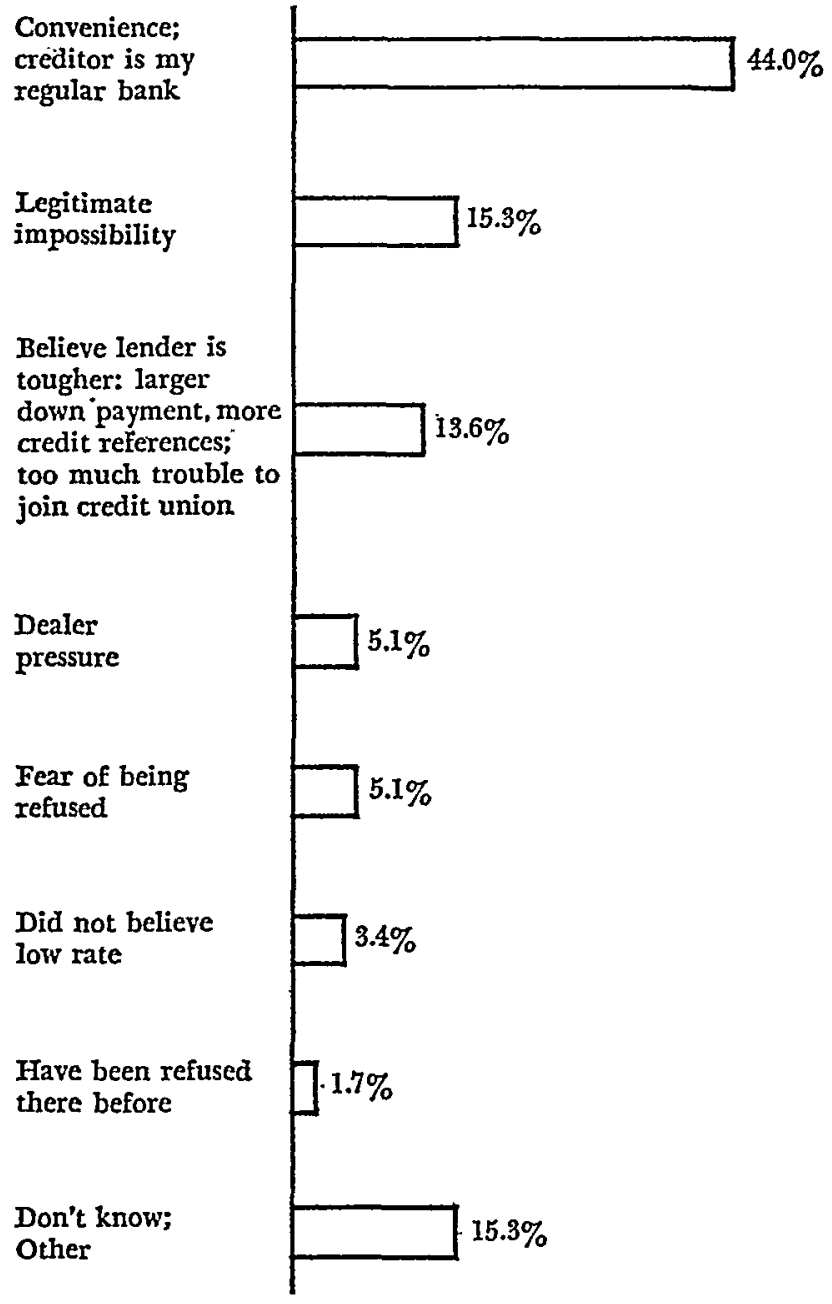

If it were somehow possible to provide money-cost information to all prospective new-car buyers before they arranged a purchase and loan, what would be the result? Nothing in our data indicates that such knowledge would have significantly changed the behavior of our respondents, and much in our data suggests that such knowledge

differences in the risks presented by the borrowers to the 3 creditors we studied in terms of income and assets held. We have shown that the lowest-rate lender would have offered the same loans to most of the customers of the other 2. 
would not have altered their behavior. The majority of the borrowers in our sample were ignorant of the interest rate they were actually paying. ${ }^{43}$ All but a small minority bought credit with the car and did not shop. ${ }^{44}$ Most borrowed near home ${ }^{45}$ and stated reasons quite unrelated to rates as a basis for their borrowing behavior. ${ }^{40}$ Finally, and most disheartening, is the substantial minority who actually knew of an institution lending at lower rates than they enjoyed but who did not stir themselves to borrow at the lower rate. ${ }^{47}$ One is reminded of the statement attributed to a cigarette company executive on the cigarette cancer warning: "I think the American public is too intelligent to pay any attention to that type of warning." The classic rejoinder also fits: "In the long run the people can be counted on."

\section{How Dw Borrowers Who Were Sensitive to Interest \\ Rate Differences Contrast with BORROWERS WHO WERE Not?}

We began this study by seeking to determine whether a substantial number of persons who had borrowed to finance the purchase of new cars could have obtained loans at interest rates lower than the ones that they were paying. Our interview with the loan officer at HVNB showed that a substantial proportion of those who had borrowed from the other lenders could have obtained a lower-cost loan. Our second step consisted of looking at new-car buyers in our sample to see how many retained rate information. We found many who had information about low-cost loans but who did not seek loans at the lower rate. We tried to determine why these buyers did not shop for loans at the lower rate. The data presented above suggest that a variety of psychological, geographical, and economic factors governs the behavior of borrowers in the consumer loan market. On the basis of those factors, we will now attempt to distinguish the borrower who shops for the low-cost loan from his nonshopping counterpart.

Most new-car buyers borrowing at the legal maximum rate had no knowledge of interest rates offered by lenders other than their

\footnotetext{
43. See Table 2 supra.

44. See note 38 supra and accompanying text.

45. See Table 3 supra.

46. See Figure 1 supra.

47. See text preceding note 40 supra and Figure 2 supra.
} 
own.18 Borrowers who were uninformed about competing lenders and who were unconcerned with interest rates or competition among lenders we will hereafter describe as "uninformed nonshoppers." 49 A small proportion (17.4\%) of the new-car buyers we interviewed did know that interest rates varied and selected a lender on that basis. These buyers may be called "shoppers."50 And a third group of respondents (29.0\%), whom we have already discussed, ${ }^{\text {,1 }}$ knew that at least one other lender in the county loaned money at a rate lower than the one that they were paying. They constitute a group of "informed nonshoppers." 22 We may begin by examining the differences among these three groups. The differences may help us explain why some new-car buyers shop for loans, why some explicitly ignore an opportunity to obtain a loan at a lower rate, and why most seem completely unaware of interest rate differences.

If one lets his imagination run, he can come up with a variety of hypothetical characteristics with which to identify those who shop and those who do not. A most obvious hypothesis is that the shoppers are more financially sophisticated than are the nonshoppers. We attempted to test this first hypothesis both by direct questioning and by asking each debtor about the type of assets that he owned; we assumed that debtors who dealt in stocks and bonds and who had several bank accounts would be more accustomed to thinking of money as a commodity to be purchased and sold. As our second hypothesis, we assumed that debtors with large incomes would be

48. See Appendix A infra, question II J.

49. The group that we will refer to as "uninformed nonshoppers" allowed the dealer to arrange their Ioan (Question II B in Appendix A), did not inquire elsewhere about the possibility of a loan (Question II B-4 in Appendix A), did not inquire about the possibility of a different loan even if they had borrowed from another creditor at another time (Questions II B-4 and II C-1 in Appendix A), did not switch creditors since the last car purchase for reasons related to the cost of the loan (Question III B in Appendix A), and did not patronize their current creditors because they offered cheap loans (Question IV $C$ in Appendix A).

50. The group that we will call "shoppers" includes those who borrowed where they did because the creditor offered cheaper loans (Questions II D-1 and IV B in Appendix A), who either switched to or stayed with a prior creditor because he offered a cheaper loan (Questions III B and C in Appendix A), and who were paying less than $\$ 6 / 100$ add-on on their loan (taken from the financing statement-see Appendix B).

51. See text preceding note 40 supra and Figure 2 supra.

52. The group that will be referred to in subsequent tables and text as the "informed nonshoppers" was assembled by sorting out all respondents who said that they had heard of a lender who would lend at a rate of interest lower than the one that they were paying (Question II J in Appendix A), who was geographically within their reach, and who did not loan only to special groups-e.g., an employee credit union for which the respondent was ineligible (Question II J-4 in Appendix A). 
more likely to shop for a low rate than would debtors with smaller incomes. A third hypothesis that we sought to test in our questioning was that the character of a debtor's job may be related to his propensity to shop-that is, a white-collar worker might be more likely to shop than a blue-collar one. Fourth, we sought to ascertain whether those debtors who shopped could be characterized as bettereducated than those who did not.

\section{A. Financial Sophistication}

In order to obtain evidence of financial sophistication, and at the same time directly to test our respondents' propensity to shop for a low-cost loan, we asked the question: "If you were to pay $\$ 6$ per 100 on a loan, would you expect it to cost the same as interest at $6 \%$ ?"53 Most of the shoppers (63.4\%) correctly answered "No"; $46.0 \%$ of the informed nonshoppers gave the correct answer; and only $21.6 \%$ of the uninformed nonshoppers knew the proper response. ${ }^{54}$

We also reasoned that those respondents who owned stocks and bonds would be more sophisticated financially than those who did not, since ownership of such assets indicates experience in treating money as a commodity. Accordingly, we expected shoppers to be more likely than either group of nonshoppers to hold stocks and bonds (see Table 4). While $46.0 \%$ of the shoppers and $42.0 \%$ of the informed nonshoppers held such assets at the time they purchased their last new car, less than $1 / 4(22.8 \%)$ of the uninformed nonshoppers owned stocks and bonds at the time of purchase. A larger proportion of uninformed nonshoppers than of either other group held no substantial assets for investment.

53. See Question II I-2 in Appendix A.

54. ANSWERs to tHE QUeSTION "IF You WeRE To PAy \$6 PER 100 ON A LOAN, WOULD You EXPECT IT To Cost The SAME AS INTEREST AT 6\%?"

\begin{tabular}{lccccr}
\hline & $\begin{array}{c}\text { Costs } \\
\text { The Same }\end{array}$ & $\begin{array}{c}\text { Costs Are } \\
\text { Different }\end{array}$ & $\begin{array}{c}\text { Don't } \\
\text { Know }\end{array}$ & Total* & N \\
\hline $\begin{array}{l}\text { Shoppers } \\
\begin{array}{l}\text { Informed } \\
\text { Nonshoppers }\end{array}\end{array}$ & $17.1 \%$ & $63.4 \%$ & $19.4 \%$ & $99.9 \%$ & 41 \\
$\begin{array}{l}\text { Uninformed } \\
\text { Nonshoppers }\end{array}$ & $28.6 \%$ & $46.0 \%$ & $25.4 \%$ & $100.0 \%$ & 50 \\
\hline
\end{tabular}

* Because percentage figures have been rounded off, the printed figures do not necessarily total $100.0 \%$. 
TABLE 4

Assets Held for Investment at Tlme of Auto Purchase

\begin{tabular}{|c|c|c|c|c|c|}
\hline & $\begin{array}{l}\text { Per cent who } \\
\text { held stocks/ } \\
\text { bonds }\end{array}$ & $\begin{array}{l}\text { Per cent who } \\
\text { held real estate } \\
\text { or other }\end{array}$ & $\begin{array}{l}\text { Per cent who } \\
\text { held no assets }\end{array}$ & Total $\uparrow$ & $\mathbf{N}$ \\
\hline Shoppers & $46.0 \%$ & $4.9 \%$ & $49.8 \%$ & $100.7 \%$ & 41 \\
\hline $\begin{array}{l}\text { Informed } \\
\text { Nonshoppers }\end{array}$ & $42.0 \%$ & $10.0 \%$ & $48.0 \%$ & $100.0 \%$ & 50 \\
\hline $\begin{array}{l}\text { Uninformed } \\
\text { Nonshoppers }\end{array}$ & $22.8 \%$ & $19.7 \%$ & $57.5 \%$ & $100.0 \%$ & 66 \\
\hline $\begin{array}{l}\text { Total } \\
\text { Nonshoppers }\end{array}$ & $31.0 \%$ & $15.5 \%$ & $53.5 \%$ & $100.0 \%$ & 116 \\
\hline
\end{tabular}

$\mathrm{X}^{2}$ (rows $\mathrm{I}$ and 2 ) $<1$, not significant.55

$\mathrm{X}^{2}$ (rows 1 and 3 ) $=8.74, \mathrm{p}<.02$.

* Does not include respondent's home.

$\uparrow$ Because percentage figures have been rounded off, the printed figures do not necessarily total $100.0 \%$.

Among the uninformed nonshoppers, the percentage that had real-estate holdings nearly equalled the percentage that invested in stocks and bonds. In contrast, a similar comparison for both shoppers and informed nonshoppers reveals that far more of the respondents in these groups invested in stocks and bonds than in real estate or other assets. Thus, it appears that shoppers were more financially sophisticated than at least uninformed nonshoppers in terms of understanding interest rates and of kinds of investments.

\section{B. Income and Home Ownership}

Arguably, the higher a borrower's income, the more likely he is to have alternatives to borrowing at an add-on rate and to be interested in finding the add-on loan that compares most favorably to a loan at simple interest. ${ }^{56}$ Prior studies have contended that consumers will absorb information when it is economically rational to do so and that consumers with a level of income high enough to give

55. Chi-square statistics have been computed for each of the tables in this section. The level of significance for a $\mathrm{X}^{2}$ value, for example $\mathrm{p}<.05$, may be interpreted as meaning that the numbers are so unevenly distributed in the table that such a distribution would occur less than $5 \%$ of the time by chance. For a significance level of $\mathrm{p}<.20$, the distribution in the table would be obtained less than 1 in 5 times by chance. These statistics should be used as an aid to intention. They do not indicate what caused the distribution of numbers in the table or how strong the relationship between two variables may be if a relationship exists. The actual numbers are included with some reluctance, but they may be valuable when differences in percentages alone are themselves misleading or inconclusive.

56. F. JUSTER \& R. SEAY, supra note 6, at 1-18. 
them alternatives will remember interest rates and shop for low-cost loans. ${ }^{57}$

If these arguments are correct, shoppers should have higher average incomes than nonshoppers. However, Table 5 shows that, while a slightly higher proportion of shoppers than nonshoppers had incomes above $\$ 15,000$, a greater proportion also had incomes below $\$ 10,000$. The mean income of both shoppers and nonshoppers fell between $\$ 10,000$ and $\$ 12,499$. Except for the tendency for shoppers to be concentrated at the extremes of the income distribution, a borrower's income does not appear to be related to his interest-rate sensitivity. A possible explanation for this failure of the statistics to bear out the theories of prior studies is that the incomes of the respondents in our sample were higher and showed much less variation than the incomes of the population of Washtenaw County as a whole. ${ }^{58}$ Thus, by inadvertently limiting our study to an unusually high-income sample, we may have obscured some significant relationships. A second possible explanation for the apparent lack of relationship between one's income level and his propensity to shop is that income makes little difference until a certain level is reached; beyond that level, consumers pay more attention to interest rates.

\begin{tabular}{|c|c|c|c|c|c|c|c|}
\hline \multicolumn{8}{|c|}{$\begin{array}{l}\text { TABLE } 5 \\
\text { INCOME }\end{array}$} \\
\hline & $\$ 0-7,499$ & $\begin{array}{c}\$ 7,500- \\
9,999\end{array}$ & $\begin{array}{c}\$ 10,000- \\
14,999\end{array}$ & $\$ 15,000+$ & N.A.* & Total & $\mathbf{N}$ \\
\hline Shoppers & $14.7 \%$ & $31.7 \%$ & $19.5 \%$ & $29.2 \%$ & $4.9 \%$ & $100.0 \%$ & 41 \\
\hline $\begin{array}{l}\text { Informed } \\
\quad \text { Nonshoppers }\end{array}$ & $14.0 \%$ & $16.0 \%$ & $46.0 \%$ & $22.0 \%$ & $2.0 \%$ & $100.0 \%$ & 50 \\
\hline $\begin{array}{l}\text { Uninformed } \\
\text { Nonshoppers }\end{array}$ & $18.2 \%$ & $25.8 \%$ & $28.8 \%$ & $24.2 \%$ & $3.0 \%$ & $100.0 \%$ & 66 \\
\hline $\begin{array}{l}\text { Total } \\
\text { Nonshoppers }\end{array}$ & $16.4 \%$ & $22.6 \%$ & $36.2 \%$ & $23.2 \%$ & $2.6 \%$ & $100.0 \%$ & 116 \\
\hline $\begin{array}{l}\mathrm{X}^{2} \text { (rows } 1 \\
\mathrm{X}^{2} \text { (rows } 1 \\
* \text { Not avail }\end{array}$ & $\begin{array}{l}\text { 2) }= \\
<2\end{array}$ & p sign & & & & & \\
\hline
\end{tabular}

57. This theory also suggests that borrowers who do not shop for low-cost loans do shop for monthly payment sizes that fit their budgets. For these borrowers, the savings on interest is not as important as the drain on assets caused by monthly payments. F. JUSTER \& R. SHAY, supra note 6, at 1-18.

58. The median income in Washtenaw County was $\$ 6,890$ in 1967 , and $23.9 \%$ of the families in the county had incomes over $\$ 10,000$. U.S. BUR. OF THE CENSUs, CounTY \& City Data Book 1967, A Statistical Abstract Supplement 183 (1967). Over half of the respondents in the survey reported incomes over $\$ 10,000$. See note 36 supra. 
But this theory does not help to explain the behavior of those whose income is below that threshold level; that is, it does not explain why some low- and moderate-income respondents shopped while others did not.

Surprisingly, we found that about twice as many nonshoppers as shoppers owned their homes outright-that is, were no longer subject to liability for mortgage or rent payments (Table 6). A possible explanation for this finding is that people who have mortgages are more aware of money as a commodity. Also, because a home mort-

TABLE 6

HOME OWNERSHIP

\begin{tabular}{lccccr}
\hline & $\begin{array}{c}\text { Per cent } \\
\text { who Own }\end{array}$ & $\begin{array}{c}\text { Per cent } \\
\text { who Mortgage }\end{array}$ & $\begin{array}{c}\text { Per cent } \\
\text { who Rent }\end{array}$ & Total & N \\
\hline $\begin{array}{l}\text { Shoppers } \\
\text { Informed }\end{array}$ & $12.2 \%$ & $61.0 \%$ & $26.8 \%$ & $100.0 \%$ & 41 \\
$\quad \begin{array}{l}\text { Nonshoppers } \\
\text { Uninformed } \\
\quad \text { Nonshoppers }\end{array}$ & $22.0 \%$ & $50.0 \%$ & $28.0 \%$ & $100.0 \%$ & 50 \\
$\begin{array}{l}\text { Total } \\
\text { Nonshoppers }\end{array}$ & $25.8 \%$ & $50.0 \%$ & $24.2 \%$ & $100.0 \%$ & 66 \\
\hline
\end{tabular}

$\mathrm{X}^{2}$ (rows 1 and 2) $=2.86, \mathrm{p}<3$.

$\mathrm{X}^{2}($ rows 1 and 3$)=2.78, \mathrm{p}<.3$.

gagor has an existing relationship with a mortgage institution, he may feel reasonably secure about going to that institution for a car loan and will find it convenient to do so.

Other studies have generally succeeded in demonstrating that knowledge of the interest rate and finance charges that one pays is related to his assets and income. ${ }^{59}$ These studies have concluded that this relationship indicates that consumers use information available to them in an economically rational manner. ${ }^{60}$ Our data, however, are inconsistent with such a conclusion; they show that amount of income and extent of asset ownership are not directly related to retention or use of information about competing interest rates. Thus, it would appear that knowledge of one's own interest rate and knowledge of competing rates are two different aspects of rate sensitivity.

59. See authorities cited in note 6 supra, especially F. JUSTER \& R: SHAY, Due, and Hoskins.

60. See F. JUSTER \& R. SHAY, supra note 6 , at 10. 


\section{Type and Length of Job}

In our interview with the HVNB loan officer, we learned that a prospective borrower may be rated not only by his income, but also by the type and stability of his job. A white-collar borrower with a steady employment record may be a more attractive prospect to a bank than a blue-collar worker who is subject to layoffs. The loan officer also seemed to respect holders of white-collar jobs for reasons unrelated to income or to job stability. Therefore, occupation and length of employment at one's present job are factors that are related to the availability of a low-cost loan. Assuming that borrowers behave rationally-and that they are aware of these lender preferences-these factors should also be related to one's sensitivity to interest rates. Table 7 shows that there was indeed a relationship between the type of job held by our respondents and their propensity to shop. The difference in occupation composition between the shoppers and the informed nonshoppers was not great, but the difference between shoppers and uninformed nonshoppers was quite substantial. Blue-collar workers constituted a significantly higher proportion of the uninformed nonshopper group than of either of the informed groups.

TABLE 7

TYPE OF JOB

\begin{tabular}{lcccc}
\hline & $\begin{array}{c}\text { White } \\
\text { Collar* }\end{array}$ & $\begin{array}{c}\text { Blue } \\
\text { Collar }\end{array}$ & Total & N \\
\hline $\begin{array}{l}\text { Shoppers } \\
\text { Informed } \\
\quad \text { Nonshoppers }\end{array}$ & $61.0 \%$ & $39.0 \%$ & $100.0 \%$ & 41 \\
$\begin{array}{l}\text { Uninformed } \\
\quad \text { Nonshoppers }\end{array}$ & $50.0 \%$ & $50.0 \%$ & $100.0 \%$ & 50 \\
$\begin{array}{l}\text { Total } \\
\text { Nonshoppers }\end{array}$ & $39.4 \%$ & $60.6 \%$ & $100.0 \%$ & 66 \\
\hline
\end{tabular}

$\mathrm{X}^{2}$ (row 1 and 2 ) $=1.11, \mathrm{p}<.28$.

$\mathrm{X}^{2}$ (rows 1 and 3 ) $=5.54, \mathrm{p}<.02$.

- Includes students.

These results seem to indicate that persons having information about competing interest rates are more likely to be white-collar than blue-collar workers and that shoppers tend to be white-collar workers. Differences in educational background, which are discussed in the next section, may partially explain these results. These results may also be due to the fact that rate information may be more readily available to persons who associate with the best credit risks. Forty-six 
per cent of the informed nonshoppers in our sample had heard of the lower-cost lender through a friend or co-worker; ${ }^{61}$ if the lowercost lenders were already lending largely to white-collar workers, it is likely that information about these lenders would be spread to other white-collar workers more effectively than to blue-collar workers.

On the average, the shoppers in our sample had held their current jobs for a shorter period of time than had the informed nonshoppers (see Table 8). About the same proportion of both groups had held their current jobs for more than 5 years. Much greater proportions of both shoppers and informed nonshoppers had held their jobs for more than 5 years than had the uninformed nonshoppers. On the other hand, more shoppers than either informed or uninformed nonshoppers had held their jobs for less than 2 years. These ambiguous findings lead to the conclusion that job

TABLE 8

Length of SERVice in Present Job

\begin{tabular}{lccccr}
\hline & $0-2$ Years & 2.5 Years & $\begin{array}{c}\text { More than } \\
\text { 5 Years }\end{array}$ & Total & N \\
\hline $\begin{array}{l}\text { Shoppers } \\
\begin{array}{l}\text { Informed } \\
\quad \text { Nonshoppers }\end{array}\end{array}$ & $45.0 \%$ & $10.0 \%$ & $45.0 \%$ & $100.0 \%$ & 40 \\
$\begin{array}{l}\text { Uninformed } \\
\quad \text { Nonshoppers }\end{array}$ & $30.0 \%$ & $24.0 \%$ & $46.0 \%$ & $100.0 \%$ & 50 \\
$\begin{array}{l}\text { Total } \\
\quad \text { Nonshoppers }\end{array}$ & $31.8 \%$ & $31.8 \%$ & $36.4 \%$ & $100.0 \%$ & 66 \\
\hline$\quad$ X2 (rows I and 2$)=6.94 \%$ & $28.5 \%$ & $40.5 \%$ & $100.0 \%$ & 116 \\
\hline
\end{tabular}

$\mathrm{X}^{2}$ (rows $\mathrm{I}$ and 2$)=6.94, \mathrm{p}<.05$.

$\mathrm{X}^{2}$ (rows $\mathrm{I}$ and 3 ) $=9.61, \mathrm{p}<.01$.

stability is not a very important factor either in the acquisition of price information or in the propensity to act on such information. Therefore, the fact that shoppers tend to be white-collar workers cannot be explained by the fact that white-collar employment is more stable than blue-collar work. It is necessary to look at some other characteristic of white-collar employees-such as their sophistication, education, place of residence, or access to information through informal channels-to explain why they constitute such a large proportion of the informed groups.

61. Another $25 \%$ read advertisements, and the remaining $29 \%$ learned of the lowerrate lender in a variety of other ways (e.g., through a professional credit counselor or by having borrowed from the lender at some time in the past). See Question II J-3 in Appendix A. 


\section{Education}

The relationship between occupation and shopping suggests that we look next at another socio-economic variable-education. Table 9 shows that, in general, the shoppers in our survey had achieved higher levels of education than had either group of nonshoppers. In fact, nearly $66 \%$ of the shoppers had attended college. The median

TABLE 9

EDUGATION

\begin{tabular}{lccccr}
\hline & $\begin{array}{c}\text { Less Than } \\
\text { 12 Years }\end{array}$ & $\begin{array}{c}\text { High School } \\
(12)\end{array}$ & $\begin{array}{c}\text { Some College } \\
(12+)\end{array}$ & Total* & N \\
\hline $\begin{array}{l}\text { Shoppers } \\
\text { Informed }\end{array}$ & $14.7 \%$ & $19.5 \%$ & $65.8 \%$ & $100.0 \%$ & 41 \\
$\quad \begin{array}{l}\text { Nonshoppers } \\
\begin{array}{l}\text { Uninformed } \\
\quad \text { Nonshoppers }\end{array}\end{array}$ & $16.6 \%$ & $39.6 \%$ & $43.8 \%$ & $100.0 \%$ & 48 \\
$\begin{array}{l}\text { Total } \\
\quad \text { Nonshoppers }\end{array}$ & $45.0 \%$ & $25.8 \%$ & $29.3 \%$ & $100.1 \%$ & 58 \\
\hline
\end{tabular}

$\mathrm{X}^{2}$ (rows 1 and 2$)=4.21, \mathrm{p}<.07$.

$\mathrm{X}^{2}$ (rows 1 and 3 ) $=15+, \mathrm{p}<.001$.

* Because percentage figures have been rounded off, the printed figures do not necessarily total $100.0 \%$.

educational attainment for the 2 groups of nonshoppers (12 years) was slightly less than that for the county as a whole (12.2 years). ${ }^{62}$ While it is tempting to interpret the differences in levels of education as a reflection of a difference in sophistication between shoppers and nonshoppers, our discussion below will show that the differences in education are also related to place of residence.

\section{E. Place of Residence}

A major difficulty in the interpretation of our data on the relative sophistication of shoppers and nonshoppers is that all of HVNB's branches are located in Ann Arbor. Because of the size of the University of Michigan, Ann Arbor has a large proportion of white-collar workers ${ }^{63}$ and a large percentage of highly educated persons. ${ }^{64}$ Therefore, the relationships that we found between knowledge and shopping and our respondents' educational attainments and job type might also be explained in part by distance

62. CountY \& CrTy Data Book, supra note 58, at 182.

63. Id. at 505. Of the employed persons in Ann Arbor, $66.2 \%$ hold white-collar jobs. The comparable national figure is $50.4 \%$.

64. Id. The median number of years of education for Ann Arbor residents is 19.7 and for all United States residents is 12.2 . 
of the residence of borrowers from each of the 3 creditors. It may be that the best banking opportunities are located near white-collar places of work and residence. That possibility prevents us from drawing the conclusion that shopping for low-cost loans is related to education and occupation. If proximity to a low-cost lender is the primary factor in a new-car buyer's decision to borrow from that lender, differences in level of education and white-collar employment may be indicative merely of the fact that HVNB is located only in Ann Arbor. Table 10 shows there was indeed a correlation be-

TABLE 10

RESPONDENTS LIVING in ANN ARBor

\begin{tabular}{|c|c|c|c|}
\hline & Per Cent & $N$ & $\mathrm{X}^{2}$ (shoppers $\mathrm{x}$ nonshoppers) \\
\hline Shoppers & $78.0 \%$ & 41 & \\
\hline \multicolumn{4}{|l|}{ Informed } \\
\hline Nonshoppers & $58.0 \%$ & 50 & $\begin{array}{c}\mathrm{X}^{2} \text { (rows } 1 \text { and } 2 \text { ) }=3.66, \\
\mathrm{p}<.06\end{array}$ \\
\hline \multicolumn{4}{|l|}{ Uninformed } \\
\hline Nonshoppers & $45.5 \%$ & 66 & $\begin{array}{c}\mathrm{X}^{2} \text { (rows I and } 3 \text { ) }=20+ \\
\mathrm{p}<.001\end{array}$ \\
\hline \multicolumn{4}{|l|}{ Total } \\
\hline Nonshoppers & $50.9 \%$ & 116 & \\
\hline
\end{tabular}

tween shopping and our respondents' places of residence. Moreover, controlling the place-of-residence factor dramatically reduces the difference in the educational background, for example, between shoppers and nonshoppers. If we consider only the Ann Arbor residents in the 3 groups, the difference in percentage of shoppers and nonshoppers respectively with more than 12 years of education declines from $30 \%$ (see Table 9 ) to $10 \%$ (see Table 11).

TABLE 11

EDUCATION of Respondents WITH RESIDENGE IN ANN ARBor

\begin{tabular}{lcccc}
\hline & $\begin{array}{c}\text { 12 Years } \\
\text { or less }\end{array}$ & $\begin{array}{c}\text { I2 Years } \\
\text { or more }\end{array}$ & $\mathrm{N}$ & $\mathrm{X}$ (shoppers x nonshoppers) \\
\hline $\begin{array}{l}\text { Shoppers } \\
\text { Informed }\end{array}$ & $34.0 \%$ & $66.0 \%$ & 32 & \\
$\quad \begin{array}{l}\text { Nonshoppers } \\
\text { Uninformed }\end{array}$ & $41.4 \%$ & $58.6 \%$ & 29 & $\mathrm{X}^{2}=.3$, not sig. \\
$\quad$ Nonshoppers & $46.6 \%$ & $53.4 \%$ & 30 & $\mathrm{X}^{2}=1$, not sig. \\
$\begin{array}{l}\text { Total } \\
\text { Nonshoppers }\end{array}$ & $44.0 \%$ & $56.0 \%$ & 59 & \\
\hline
\end{tabular}

Comparative analysis of our 3 groups of respondents has allowed us to identify some characteristics that seem to be associated with 
borrowers who shop, some that seem to be associated with borrowers who know of competing interest rates but do not take advantage of them, and some that seem to be associated with borrowers who neither shop nor have information. ${ }^{65}$ We found that the amount of the debtor's income and the type of assets he held had no significant relationship to his status as a shopper or nonshopper; in fact, the nonshoppers earned slightly more money than did the shoppers. In contrast, we found that those persons with some sophistication in interpreting interest rates were much more likely to shop. Not surprisingly, we also found that a borrower who knew the rate of interest he was paying was far more likely to be a shopper than a nonshopper, that a highly educated person was more likely to be a shopper than was one who was not highly educated, and that shoppers were more likely to be white-collar workers than blue-collar workers. While we offer hypotheses for the independent effects that each of these variables has on shopping, we cannot sort out the relative contribution of each. Our data strongly suggest that shoppers tend to be middle-class consumers, consumers with fairly conservative buying patterns. From our sample, such consumers seem to enjoy a variety of advantages: they live near the low-cost lenders, they are more likely to understand the meaning of the add-on rate of interest, and, as may be inferred from our interview with a loan officer, banks are likely to pay greater respect to them because of their white-collar jobs.

The kindest thing that can be said for these findings is that they are interesting but inconclusive. A variety of factors have confounded our search for certainty. The fact that HVNB, the low-cost lender, is located only in Ann Arbor, a town whose population has a disproportionately high level of education, causes us some fear that in reporting that shoppers are highly educated persons we are really

65. In reading this discussion of the differences between shoppers and both groups of nonshoppers, one should keep in mind that we have been considering the composition of each of the groups and not the likelihood that a white-collar worker or an individual with an income under $\$ 10,000$ will be a shopper. The group that we label "shoppers" is so small-about $17.5 \%$ of our sample-that its members are a small minority of all those new-car buyers with each of the characteristics we have discussed. What we have shown is that an individual with certain demographic characteristicssuch as high income and white-collar job-is more likely to be a shopper than is one not possessing such characteristics. But it does not follow that the possession of such characteristics makes it more likely that a particular individual will be a shopper than a nonshopper. We have not compared percentages of white-collar workers in each of the 3 groups because our 3 groups combined do not include all respondents in our sample and the percentages would not give proportions of a statistically representative sample of white- and blue-collar workers. Our 3 comparison groups comprise about $65 \%$ of our entire sample; the remaining $35 \%$ do not fall into any of the groups. 
only saying that a lot of college graduates live in Ann Arbor. Furthermore, we are inclined to qualify our figures on income because we believe the HVNB sample included a disproportionately high number of students who will shortly be high-income earnerspersons who have all of the attributes of a high-income earner but are now classified as low- or no-income persons because they are still law or medical students. We must conclude this analysis, then, with a bit of a disclaimer-we are not sure that our questions plumbed the depths as well as they might have.

\section{Conclusion}

Our principal conclusion is that the consumer loan market, at least as it is evidenced in the market for new-car loans in Washtenaw County, is a grossly imperfect one-grossly imperfect, that is, if one regards it as a market whose single item of cost is the rate of interest one pays. We found that many who live in the county failed to seek the lowest-cost loan for which they could have qualified. We conclude that the lack of knowledge of the lower interest rate was not the principal deterrent to procuring such a loan, but that a variety of factors, in various combinations, kept the bulk of our respondents from obtaining a lower-cost loan.

The results of our study suggest that, at least with regard to auto loans, the disclosure provisions of the Truth-in-Lending Act will be largely ineffective in changing consumer behavior patterns. ${ }^{66}$ Certainly the Act will not improve the status of those who already know that lower rates are available elsewhere. And we discovered no evidence that knowledge of the interest rate-which, even under the Act will usually come after a tentative agreement to purchase a specified car has been reached ${ }^{67}$-will stimulate a substantial percentage of consumers to shop for a lower rate elsewhere. If there will be a beneficiary of truth-in-lending, our data indicate that he will be a middle-class borrower, the man with a better-than-average job and education, not the blue-collar worker. Our data suggest that even the relatively affuent blue-collar employee will not benefit from rate disclosure; presumably, the low-income blue-collar employee will benefit even less.

66. Preliminary confirmation from a more recent survey appeared in the N.Y. Times, Feb. 7, 1971, \& A, at 24, col. 1. which reported that a Federal Reserve Board survey of consumers' knowledge of interest rates showed slight improvement between 1969 and 1970.

67. See note 12 supra and accompanying text. 
If truth-in-lending is not a panacea for the imperfections in the market, then what should legislatures do? One desirable act would be to break down the barriers that now exist to market entry by new lenders. Although our study shows that there are many who would not benefit from the entry of new and lower-cost creditors, none of the many respondents who borrowed at a low cost from HVNB could have so benefited prior to its entry into the market in 1963. The addition of new lenders, of course, does not ensure that there will be rate competition. Moreover, one suspects that rate competition will always be limited to big-ticket items. There is always the chance, however, that the newcomer will see some advantage in offering a rate differential.

Another possibility for new legislation would be an expansion of the truth-in-lending laws to require lenders who advertise to disclose in their advertisements the rates at which they make various loans. The current law provides that lenders who undertake to advertise interest rates must disclose those rates in specified terms; ${ }^{68}$ but lenders remain free to ignore rates entirely in their advertising. Indeed, a recent GMAG television advertisement features a heavybreathing jogger. The point of the ad is that it is much more convenient to come to GMAC to buy the car and borrow in one spot than it is to run to one place for insurance, to another place for a loan, and to a third place for the car. Perhaps GMAC should be required in such an advertisement to disclose the rate at which it will lend against new cars. However, our findings make us rather pessimistic about the effectiveness of disclosures, whenever and however made, in today's market.

Widespread public education, through television and through the schools, offers greater possibilities. Such education might disclose some of the tricks of the trade, might teach the public how to compute interest charges, and might encourage more consumers to seek out lower-cost lenders. Of course, the sample of respondents that we interviewed were not typical of all consumers; nor did they represent some of the classes of consumers to whom most concern should be directed. In this sense we are talking only about consumers who are relatively well-off. It is quite unclear whether relatively affluent consumers like those we interviewed-even armed with rate information and brainwashed by television instruction about finding cheap loans-would change their behavior. If they do

68. Reg. Z, 12 C.F.R. § 226.10(d)(1) (1970). 
not, then we suppose that is the consumers' business. If dealing with "Harry" down at the local dealership instead of with some unknown banker, if doing one-stop shopping instead of two- or three-stop shopping, and if closing the entire deal on the car at once are all worth $\$ 120$ or $\$ 130$ to the consumer, then why shouldn't we let him spend his money that way?

69. It is worthwhile to emphasize the differences in the authors' approaches to consumer protection. While the data show that most of our respondents were financially well-off, the imperfections that we found in the market do not necessarily reflect either a lack of interest in savings or some other completely voluntary inaction. It is true that a consumer need not save his money. But a less well-educated, blue-collar consumer may show justifiable reluctance to deal with bankers and prefer to deal instead with "easy-credit" lenders. The HVNB loan officer's statement that he judged partly on appearance and white-collar job is a tip-off to some of the more subtle pressures in the credit market that we could not measure. Distances from places of work and residence to the lower-priced creditors is another. Moreover, even if the lowest-cost loans were equally available to all, it would seem desirable in a creditoriented society to teach people-especially those with limited resources-how to use credit wisely. In the alternative, or as a supplement, a form of regulation that both facilitates the granting of credit to all and that transfers some of the cost of granting credit to the general public either through better protection or direct subsidy might be helpful. Until these and other remedies are tried, the "ho-hum" attitude toward consumer credit seems inappropriate. 


\section{APPENDIX A}

\section{QuestionNaIre For DeBtor ${ }^{1}$}

(Do not accept other family members.)

I am

from the University of Michigan Law School. You probably received a letter which said that we would be calling. As we said in the letter, we are doing a study of consumer credit in Washtenaw County and of the attitudes and plans of consumers. We have selected your name by chance from a list of people who bought late model cars in 1967. If you will give me a few minutes of your time in helping me fill out this questionnaire it will greatly help our study. All information will be used anonymously. No one's name will ever appear in the report. We will be happy to send you a copy of the final report if you want. In fact, it may help you the next time you buy a car.

\section{Code}

Frequency Percent ${ }^{2}$

I. General Information

A. Name:

B. Address:

$\begin{array}{lrc}\text { Ann Arbor } & 137 & 58.3 \% \\ \text { Ypsilanti } & 44 & 18.7 \\ \text { Dexter } & 15 & 6.4 \\ \text { Other } & 37 & 15.8 \\ \text { N.A. } & 2 & 0.8\end{array}$

C. Date of Birth (by age):

$\begin{array}{lrc}10-20 \text { years: } & 1 & 0.4 \% \\ 21-30 & 62 & 26.4 \\ 31-40 & 58 & 24.7 \\ 41-50 & 53 & 22.6 \\ 51-60 & 33 & 14.0 \\ 60+ & 10 & 4.3 \\ \text { N.A. } & 18 & 7.7\end{array}$

D. Marital Status:

Married

Widowed

$186 \quad 79.1 \%$

Divorced

1.3

Single

5.5

N.A.

13.2

$\begin{array}{rr}31 & 13.2 \\ 2 & 0.9\end{array}$

E. Race:

$\begin{array}{lrr}\text { Black } & 19 & 8.1 \% \\ \text { White } & 209 & 88.9\end{array}$

1. Indicating the aggregate of all answers given.

2. Not weighted to compensate for the double proportion of HVNB borrowers.

3. Not available. 


\section{Frequency Per cent}

Other

N.A.

$\begin{array}{ll}2 & 0.9 \\ 5 & 2.1\end{array}$

F. Sex:

$\begin{array}{lrc}\text { Male } & 195 & 83.0 \% \\ \text { Female } & 34 & 14.5 \\ \text { N.A. } & 6 & 2.5\end{array}$

G. Number of Children Living at Home:

$\begin{array}{lrc}0 & 75 & 31.9 \% \\ 1 & 36 & 15.3 \\ 2 & 51 & 21.7 \\ 3 & 22 & 9.4 \\ 4 & 17 & 7.2 \\ 5 & 4 & 1.7 \\ 6 & 3 & 1.3 \\ 7 & 2 & 0.9 \\ 8+ & 2 & 0.9 \\ \text { N.A. } & 23 & 9.8\end{array}$

II. First I would like to talk about the general details of the last car purchase you made.

A. From whom did you borrow:

$\begin{array}{lrc}\text { GMAC } & 70 & 29.8 \% \\ \text { AAB } & 101 & 43.0 \\ \text { HVNB } & 63 & 26.8 \\ \text { Don't know } & 1 & 0.4\end{array}$

B. (If at GMAC or AAB) Did the dealer arrange the loan? If no, go to $C$.

\begin{tabular}{|c|c|c|}
\hline Yes & 128 & $54.5 \%$ \\
\hline No & 44 & 18.7 \\
\hline $\begin{array}{c}\text { HVNB loan (not arranged } \\
\text { by dealer) }\end{array}$ & 62 & 26.4 \\
\hline N.A. & 1 & 0.4 \\
\hline
\end{tabular}

If yes: 1. Was everything taken care of at the dealer's office or did you go to the GMAC/AAB office?

$\begin{array}{lrc}\text { Yes } & 121 & 51.5 \% \\ \text { No } & 7 & 3.0 \\ \text { Dealer did not arrange loan } & 102 & 43.4 \\ \text { Don't know, N.A. } & 5 & 2.1\end{array}$

2. Did you sign the contract on the same visit to the dealer's when you orally agreed to buy the car?

$\begin{array}{lrc}\text { Yes } & 80 & 34.0 \% \\ \text { No } & 47 & 20.0 \\ \text { Dealer did not arrange loan } & 102 & 43.4 \\ \text { Don't know, N.A. } & 6 & 2.6\end{array}$




\section{Frequency Per cent}

3. If you had gotten your loan somewhere else, do you think that the dealer would have sold you the car for the same price?

$\begin{array}{lrc}\text { Yes } & 109 & 46.4 \% \\ \text { No } & 16 & 5.8 \\ \text { Dealer did not arrange loan } & 102 & 43.4 \\ \text { Don't know, N.A. } & 8 & 3.4\end{array}$

4. Did you inquire elsewhere about the possibility of a loan?

$\begin{array}{lrc}\text { Yes } & 16 & 7.0 \% \\ \text { No } & 115 & 48.9 \\ \text { Dealer did not arrange loan } & 102 & 43.4 \\ \text { Don't know, N.A. } & 2 & 0.8\end{array}$

If yes: a. Where?

HVNB

$\mathrm{AAB}$

$2 \quad 0.9 \%$

Other

1.3

$11 \quad 4.8$

b. Why didn't you borrow there?

$\begin{array}{lrr}\text { Not cheaper } & 7 & 3.0 \% \\ \text { Present creditor } & & \\ \quad \text { more convenient } & 2 & 0.9 \\ \text { Dealer pressure } & 1 & 0.4 \\ \text { Other } & 4 & 1.7 \\ \text { Dealer did not arrange or did } & & \\ \quad \text { not inquire elsewhere } & 218 & 92.8 \\ \text { Don't know, N.A. } & \mathbf{3} & 1.2\end{array}$

If no: a. Is there some reason why you did not inquire elsewhere?

Convenient to do business this way, short on time

Have dealt with this creditor before

Dealer pressure

Present creditor is cheapest

Low credit rating-had no choice

Other

$19 \quad 8.1 \%$

Dealer did not arrange or inquired elsewhere

$46 \quad 19.8$

$8 \quad 3.4$

$12 \quad 5.1$

Don't know, N.A.

$4 \quad 1.7$

$27 \quad 11.5$

$116 \quad 49.4$

$3 \quad 1.3$

b. Did the dealer either encourage or discourage you from inquiring elsewhere about a loan?

$\begin{array}{lrc}\text { Encouraged } & 2 & 0.9 \% \\ \text { Discouraged } & 6 & 2.6 \\ \text { Neither } & 119 & 50.6 \\ \text { Dealer did not arrange loan } & 103 & 43.8\end{array}$




\section{Frequency Per cent}

Don't know, N.A.

i. How?

$\begin{array}{ll}5 & 2.1 \\ \begin{array}{r}\text { Number of } \\ \text { responses }\end{array} & 10\end{array}$

If HVNB or if dealer did not arrange the loan:

C. Do you think that if you had financed through the dealer he would have sold you the automobile at a different price?

Yes

No

Dealer arranged loan

Don't know, N.A.
16

70

125

24
$6.7 \%$

29.8

53.2

10.2

1. Did the dealer offer to arrange a loan?

Yes

No 52

Dealer arranged loan

Don't know, N.A.

a. If yes: How did his offer compare with the loan you actually received?

$\begin{array}{lrc}\text { Higher } & 20 & 8.5 \% \\ \text { Lower } & 32 & -13.6 \\ \text { Same } & 50 & 21.3 \\ \text { No } & 126 & 53.6 \\ \text { Dealer arranged loan } & 6 & 2.5 \\ \text { Don't know, N.A. } & \end{array}$

2. (If not financed at HVNB) Did you mention HVNB? No respondent mentioned HVNB

3. If the dealer made a competitive offer, why didn't you accept it?

Easier not to

Cheaper not to

Prefer to do it myself

Hostile to car dealers

Other

$\begin{array}{ll}7 & 3.0 \% \\ 2 & 0.9 \\ 4 & 1.7 \\ 3 & 1.3 \\ 4 & 1.7\end{array}$

No competitive offer, or dealer arranged loan $\quad 201 \quad 85.5$

Don't know, N.A. $\quad 14 \quad 5.9$

D. (If financed at $A A B$ or $H V N B$ ) Is $A A B / H V N B$ your regular bank?

$\begin{array}{lll}\text { Yes } & 120 & 51.1 \% \\ \text { No } & 115 & 48.9\end{array}$

1. (If no or if financed at GMAC) Is there some reason why you did not finance the car at your regular bank?

Easier to borrow from present creditor

Cheaper

Took dealer's advice

$\begin{array}{rl}7 & 3.0 \% \\ 20 & 8.5 \\ 7 & 3.0\end{array}$




\section{Frequency Per cent}

Had contact with this cred-

$\begin{array}{lrr}\text { itor before } & 10 & 4.3 \\ \text { Other } & 16 & 6.9 \\ \text { Don't know, N.A. } & 55 & 23.4\end{array}$

E. How far do you live (work) from the dealer?

$\begin{array}{lrc}0-1 \text { mile } & 32 & 13.6 \% \\ 1-5 & 76 & 32.3 \\ 5-10 & 59 & 25.1 \\ 10+ & 59 & 25.1 \\ \text { Don't know, N.A. } & 9 & 3.8\end{array}$

F. How far do you live (work) from your regular bank?

$\begin{array}{lrc}0-1 \text { mile } & 115 & 48.9 \% \\ 1-5 & 84 & 35.7 \\ 5-10 & 15 & 6.4 \\ 10+ & 12 & 5.4 \\ \text { Don't know, N.A. } & 9 & 3.8\end{array}$

G. (If financed at bank other than regular bank) How far do you live (work) from the bank where you financed the car?

$\begin{array}{lrl}0-1 \text { mile } & 8 & 3.4 \% \\ 1-5 & 16 & 6.8 \\ 5-10 & 7 & 3.0 \\ 10+ & 12 & 5.2 \\ \text { Financed through regular } & & \\ \quad \text { bank } & 121 & 51.5 \\ \text { Don't know, N.A. } & 71 & 30.2\end{array}$

$\mathrm{H}$. What interest rate are you paying on your loan?

$\begin{array}{lrr}4.0 \% & 7 & 3.0 \% \\ 4.5 & 37 & 15.7 \\ 5.0 & 28 & 11.9 \\ 5.5 & 12 & 5.1 \\ 6.0 & 51 & 21.7 \\ 6.5+ & 18 & 7.7 \\ \text { Don't know, N.A. } & 82 & 34.9\end{array}$

I. Do you know what interest rate banks are paying on savings?

$\begin{array}{lrc}3.5 \% & 9 & 3.8 \% \\ 4.0 & 44 & 18.7 \\ 4.5 & 65 & 27.7 \\ 5.0 & 45 & 19.1 \\ 5.5 & 19 & 8.1 \\ 6.0+ & 1 & 0.4 \\ \text { Don't know, N.A. } & 52 & 22.1\end{array}$

1. Do you know if it is computed on the same basis?

Respondent says yes

Respondent says no or gives

17

$7.2 \%$

explanation

104

44.2 
Other wrong answer

$\begin{array}{cc}\text { Frequency } & \text { Per cent } \\ 27 & 11.6 \\ 87 & 37.0\end{array}$

2. If you were to pay $\$ 6$ per hundred on a loan, would you expect it to cost you the same as interest at $6 \%$ ?

Respondent says yes

67

$28.5 \%$

Respondent says no or gives explanation

$94 \quad 40.0$

Other wrong answer

$28 \quad 12.0$

Don't know, N.A.

$46 \quad 19.5$

J. Do you know of anyone in Washtenaw County who lends at a lower rate than you borrowed?
Yes
59
172
$25.5 \%$
No

$\begin{array}{rc}17 & 7.2 \% \\ 7 & 3.0 \\ 35 & 15.3 \\ 172 & 74.5\end{array}$

If yes: 1 . Who?

FVNB

$\mathrm{AAB}$

Other

172

15.3

No

$\begin{array}{rl}5 & 2.1 \% \\ 53 & 22.6 \\ 173 & 73.6 \\ 3 & 1.7\end{array}$

3. How did you find out about the lower rates? (word of mouth, ads, etc.)

Word of mouth, general knowledge

Friend or co-worker

Professional advice

Regular prior contact

Ad

Other

$\begin{array}{rl}19 & 8.1 \% \\ 10 & 4.3 \\ 1 & 0.4 \\ 4 & 2.6 \\ 12 & 5.2 \\ 4 & 1.7 \\ & \\ 175 & 73.6 \\ 10 & 4.2\end{array}$

Don't know anyone with lower rate

4. Why didn't you borrow there?

Took dealer's advice

Did not believe or trust

Respondent is high credit risk

$4 \quad 1.7 \%$

20.9

Present arrangement is more convenient

Inconvenience-respondent

believes low-cost creditor requires more credit references or higher down payment 
Frequency

Per cent

Impossibility-creditor is in another city, lends only to members, etc.

$\begin{array}{rr}10 & 4.3 \\ 178 & 75.7 \\ 10 & 4.3\end{array}$

Don't know anyone lower

Don't know, N.A., other

4.3

K. Do you read the Ann Arbor News regularly? The Ypsilanti Press?

$\begin{array}{lrc}\text { Ann Arbor News } & 166 & 70.6 \% \\ \text { Ypsilanti Press } & 26 & 11.1 \\ \text { Neither } & 28 & 11.9 \\ \text { Both } & 12 & 5.1 \\ \text { N.A. } & 3 & 1.3\end{array}$

If yes: 1. Have you ever noticed ads concerning rates?

Yes

No

$98 \quad 41.7 \%$

Don't know, N.A., don't read paper

$40 \quad 17.1$

If yes: a. Who was the advertiser(s)?

HVNB

$\mathrm{AAB}$

Other

$76 \quad 32.3 \%$

GMAC

\begin{tabular}{rl}
8 & 3.4 \\
14 & 6.0 \\
\hline
\end{tabular}

b. Do you remember the rates advertised?

Yes $-4.0 \%$ or below

Yes-4.5

Yes-5.0

Yes-5.5+

No

Recalls ad was for cheap loan

N.A., does not read paper, or did not see ads

$\begin{array}{rc}6 & 2.6 \% \\ 37 & 15.7 \\ 7 & 3.0 \\ 9 & 3.8 \\ 45 & 19.1 \\ 4 & 1.7 \\ & \\ 127 & 54.1\end{array}$

L. Do you know the total amount of the finance charge on your loan?

Respondent's guess was three times greater than actual finance charge

2-3 times

1.25-2 times

$.75-1.25$ times

$.50-.75$ times

less than .50 finance charge

Actual finance charge unavailable

Don't know and did not guess at finance charge

$\begin{array}{rr}3 & 1.3 \% \\ 2 & 0.9 \\ 18 & 7.7 \\ 60 & 25.5 \\ 11 & 4.7 \\ 5 & 2.2 \\ & \\ 59 & 25.1 \\ 77 & 32.8\end{array}$


Frequency Per cent

III. Have you ever bought a new car before?

$\begin{array}{lrc}\text { Yes } & 188 & 80.0 \% \\ \text { No } & 43 & 18.3 \\ \text { N.A. } & 4 & 1.7\end{array}$

If yes:

A. Have you ever dealt with before?

dealer

1. If yes, did he arrange your financing before?

2. If no, when you bought your car from other dealers, did did they arrange your financing?

Yes, same dealer arranged loan

Yes, same dealer did not arrange

43

$18.3 \%$

Yes, different dealer who arranged loan

14.0

Yes, different dealer who did not arrange loan

Never bought new car before

$62 \quad 26.4$

N.A.

50

43

$4 \quad 1.7$

3. If no, why did you have the dealer arrange it this time?

Dealer did not arrange last loan or never bought new car before

Easier

$\begin{array}{rc}200 & 85.1 \% \\ 9 & 3.8\end{array}$

Cheaper

Could not pay cash this time

Other

$2 \quad 0.9$

N.A.

$\begin{array}{ll}4 & 1.7\end{array}$

$8 \quad 3.5$

$12 \quad 5.1$

B. Did you deal with bought a new car?

Yes when you previously

No

$\begin{array}{rl}116 & 49.3 \% \\ 64 & 27.1 \\ 48 & 20.4 \\ 7 & 3.0\end{array}$

Never bought new car before

$7 \quad 3.0$

1. If no, can you tell me why you switched to

bank or

GMAC

(convenience, lower rates, service, dealer influencing)

Lower interest

Convenience

Dealer's recommendation

20

Other

16

$8.5 \%$

6.8

$8 \quad 3.4$

8.5 
Frequency Per cent

2. If yes, why did you stay with the same company?

Convenient or the present creditor is regular bank Familiar with this creditor and trust him
Lower interest rate

$45 \quad 19.1 \%$

Dealer's recommendation

$15 \quad 6.4$

$9 \quad 3.8$

C. Have you ever borrowed from other banks or finance companies?

Yes

No 151

N:A.

1. If yes, did you consult them about financing the car?

Consulted

Did not consult

15

136

$6.4 \%$

Never borrowed from another creditor or N.A.

2. Why or why not?

Respondents who consulted another creditor:

Know and trust him

5

Gave him first chance because borrowed there before

10

Respondent was turned down

Did not consult, had never borrowed before, or N.A.

Respondents who did not consult another creditor:

Did not consult because:

Other more expensive or tougher on late payments

Fear of refusal

$\begin{array}{rc}38 & 16.2 \% \\ 5 & 2.1 \\ 58 & 24.7 \\ 7 & 3.0 \\ & \\ 28 & 11.9 \\ 99 & 42.1\end{array}$

D. Do you work during banking hours?

Yes

179

No

Don't know banking hours

1. What hours do you work?

Day shift

Night or afternoon shift

N.A.

$\begin{array}{rc}112 & 47.7 \% \\ 6 & 2.6 \\ 117 & 49.7\end{array}$


Frequency Per cent

2. Were the hours the bank stays open important in selecting your bank?

Yes

$\begin{array}{rl}62 & 26.4 \% \\ 166 & 70.6 \\ 7 & 2.9\end{array}$

IV. Future Transactions

A. When you buy your next car, do you think you will borrow from bank or GMAC

$\begin{array}{lrc}\text { Yes } & 143 & 60.8 \% \\ \text { No } & 60 & 25.5 \\ \text { Pay cash next time } & 6 & 2.6 \\ \text { Don't know, N.A. } & 26 & 11.0\end{array}$

B. Is there anything you particularly like about $\frac{}{\text { bank or GMAC }}$ ?

C. Is there anything you particularly dislike about

bank or

No likes, no complaints

GMAC

Complaints about loan service

$83 \quad 35.3 \%$

Satisfied customer

$5 \quad 2.1$

Satisfied with loans (specifically)

$78 \quad 33.2$

This creditor easier on late payments, or easy credit

Mixed reaction-some likes, some complaints

Don't know, N.A.

$24 \quad 10.2$

$18 \quad 7.7$

$21 \quad 9.0$

$4 \quad 1.7$

D. Have you recommended to anyone?

1. If yes, what did you recommend?

Recommended generally to relative

Recommended generally to friend

Recommended loan service to anyone

Other recommendations

No recommendations

Don't know, N.A.

$\begin{array}{rc}3 & 1.3 \% \\ 1 & 0.4 \\ 34 & 14.4 \\ 52 & 22.1 \\ 140 & 59.6 \\ 5 & 2.1\end{array}$

E. Has anyone recommended any other bank or finance company to you? If yes, what did they recommend about it?

Recommended HVNB loans

Recommended HVNB for any

other reason $9 \quad 3.8 \%$

$11 \quad 4.7$ 
Frequency Per cent

Recommended other creditor's loan service $12 \quad 5.1$

Recommended other creditor for any other reason $\quad 33 \quad 14.0$

No recommendations $\quad 166 \quad 70.6$

Don't know, N.A. $\quad 4 \quad 1.7$

V. The final set of questions concerns the kind of information bank or GMAG asked of you when they decided that you were

a good borrower. We are trying to find out how the banks decide whom they will finance and whom they will not finance. As I said before, the information you give will be strictly confidential, and your name will never appear. We are just trying to find out how banks and finance companies work.

A. How far have you gone in school? (Hand card to person.)

$\begin{array}{lrc}\text { Less than 6th grade } & 3 & 1.3 \% \\ 6-8 & 21 & 8.9 \\ 9-11 & 27 & 11.5 \\ \text { High school graduate } & 65 & 27.7 \\ 13-15 & 30 & 12.8 \\ \text { 16+, college graduate } & 73 & 31.1 \\ \text { N.A. } & 16 & 6.8\end{array}$

B. What was your job(s) at the time you purchased your car?

1. Who was your employer(s) at the time of purchase?

\section{Not Coded}

2. How long had you been working there at the time of purchase?

$\begin{array}{lrc}\text { Less than I year } & 36 & 15.3 \% \\ 1-2 & 27 & 11.5 \\ 2-5 & 54 & 23.0 \\ 5-10 & 35 & 14.9 \\ 10+ & 64 & 27.2 \\ \text { Unemployed or student } & 13 & 5.5 \\ \text { N.A. } & 6 & 2.5\end{array}$

3. What kind of work did you do there at the time of purchase?

Salaried professional

Salaried engineer

Self-employed professional

Self-employed manager

Salaried management

Other white collar

$\begin{array}{rl}36 & 15.3 \% \\ 8 & 3.4 \\ 5 & 2.1 \\ 18 & 7.7 \\ 22 & 9.4 \\ 21 & 8.9\end{array}$

Semi-skilled or skilled blue collar

$41 \quad 17.4$

Unskilled blue collar

N.A.

$68 \quad 28.9$

$\begin{array}{ll}3 & 1.3\end{array}$


C. Do you:

Frequency Per cent
1. Own your own house?

$\begin{array}{rl}45 & 19.1 \% \\ 118 & 50.2 \\ 66 & 28.1 \\ 6 & 2.5\end{array}$
2. Pay on a mortgage?
3. Rent?

D. Did you own any other assets at the time of the purchase?

Stocks or bonds

Checking account only

Savings account

8

23

88

Real property and savings account

Stocks or bonds and some savings

Real property and stocks or bonds

Real property, stocks or bonds, and savings

N.A.

Life insurance

Less than $\$ 15,000$

$15-30,000$

$30-50,000$

$50,000+$

Did not or would not give amount

No life insurance

N.A.

$\begin{array}{rc}27 & 11.5 \\ 60 & 25.5 \\ & \\ 4 & 1.7 \\ 15 & \\ 7 & 6.4 \\ & 3.0 \\ 30 & 12.8 \% \\ 16 & 6.8 \\ 12 & 5.1 \\ 7 & 3.0 \\ & \\ 134 & 57.0 \\ 27 & 11.5 \\ 9 & 3.8\end{array}$

E. (If respondent had savings or stocks)

1. Some people use their savings or sell stock to purchase an automobile. Why did you choose instead to borrow?

Easier to do so

Cheaper in the long run, or

$7 \quad 3.0 \%$

it would establish my credit

Reluctance to use savings

Dealer pressure

Did not have enough savings

Other

Used savings

Don't know

N.A., or no savings

\begin{tabular}{rrr}
28 & & 11.9 \\
71 & & 30.2 \\
\hline 68 & & 28.9 \\
8 & & 3.4 \\
3 & & 1.3 \\
12 & & 5.1 \\
29 & & 12.3
\end{tabular}

2. a. If the interest on your loan had been $12 \%$ per year, would you have used your savings or sold your stock instead of borrowing?

b. Even if the monthly payment would have been the same?

Yes, would do different to both parts 


\section{Frequency Per cent}

Yes to part a; no, would do same to part $b$

$8 \quad 3.4$

No, would do same to both parts; interest is the same as mine

$56 \quad 23.9$

Other

Don't know, N.A., no savings, or savings too small to matter

$4 \quad 1.7$

$62 \quad 26.4$

F. If no savings, stocks, or bonds:

If the interest on your loan had been $12 \%$ per year instead of what you are paying, would you have acted differently in buying your car or getting your loan (e.g., put off purchase, purchase cheaper car, etc.)?

Yes, would not have borrowed

Yes, would have put off purchase

Yes, other $20.9 \%$

No, no change

Had savings, or N.A.

$\begin{array}{rr}23 & 9.8 \\ 10 & 4.3 \\ 16 & 6.8 \\ 184 & 78.3\end{array}$

G. Did your wife (husband) work at the time of the purchase? (kind of work, etc.)

$\begin{array}{lrc}\text { Salaried professional } & 11 & 4.7 \% \\ \text { Salaried engineer } & - & - \\ \text { Self-employed professional } & 3 & - \\ \text { Self-employed manager } & 3 & 1.3 \\ \text { Salaried manager } & 2 & 1.3 \\ \text { Other white collar } & 3 & 0.9 \\ \text { Skilled and semi-skilled } & 47 & 1.3 \\ \text { Unskilled } & 136 & 50.0 \\ \text { Does not work } & 30 & 12.8 \\ \text { N.A. } & \end{array}$

H. What was her (his) income category?

$\begin{array}{lrc}\text { Under } \$ 3,000 & 3 & 1.3 \% \\ 3,000-4,999 & 12 & 5.1 \\ 5,000-7,499 & 3 & 1.3 \\ 7,500-9,999 & 4 & 1.7 \\ 10,000-12,499 & -1 & - \\ 12,500-14,999 & 1 & 0.4 \\ 15,000-19,999 & 1 & 0.4 \\ 20,000 \text { and up } & 1 & 0.4 \\ \text { Does not work } & 136 & 57.8 \\ \text { N.A. } & 74 & 31.9\end{array}$


Frequency Per cent

I. Into which category did your family income fall at the time of the purchase?
Under $\$ 3,000$
$3,000-4,999$
$5,000-7,499$
$7,500-9,999$
$10,000-12,499$
$12,500-14,999$
$15,000-19,999$
over 20,000
N.A.

$\begin{array}{rc}2 & 0.9 \% \\ 9 & 3.8 \\ 28 & 11.9 \\ 53 & 22.6 \\ 48 & 20.4 \\ 27 & 11.5 \\ 31 & 13.2 \\ 22 & 9.4 \\ 15 & 6.4\end{array}$




\section{APPENDIX B}

InFormation ObTained from Financing Statements ${ }^{1}$

1. Name of Debtor:

2. Address of Debtor:

3. Phone number:

4. Type of car and model:

5. a) Total price + insurance:

$\begin{array}{ccc}\text { Code } & \text { Frequency } & \text { Per cent } \\ \$ 0-1800 & 1 & 0.4 \% \\ 1801-2200 & 24 & 10.2 \\ 2201-2500 & 17 & 7.2 \\ 2501-2800 & 39 & 16.6 \\ 2801-3000 & 27 & 11.5 \\ 3001-3200 & 28 & 11.9 \\ 3201-3500 & 29 & 12.3 \\ 3501-4200 & 25 & 10.6 \\ 4201+ & 16 & 6.8 \\ \text { N.A. } & 28 & 11.3\end{array}$

b) Down payment or trade-in:

$\$ 0$
$1-200$
$201-300$
$301-500$
$501-700$
$701-1000$
$1001-1500$
$1501+$
N.A.

$\begin{array}{rr}8 & 3.4 \% \\ 18 & 7.7 \\ 29 & 12.3 \\ 34 & 14.5 \\ 37 & 15.7 \\ 28 & 11.9 \\ 33 & 14.0 \\ 20 & 8.5 \\ 28 & 11.3\end{array}$

c) Total time balance:

\begin{tabular}{lcc}
$\$ 0-1000$ & 2 & $0.9 \%$ \\
$1001-1600$ & 22 & 9.4 \\
$1601-2000$ & 25 & 10.6 \\
$2001-2600$ & 54 & 23.0 \\
$2601-3000$ & 39 & 16.6 \\
$3001-3400$ & 29 & 12.3 \\
$3401-4200$ & 38 & 16.2 \\
$4201+$ & 10 & 4.3 \\
N.A. & 16 & 6.8 \\
\hline
\end{tabular}

1. See note 16 supra and accompanying text.

2. Not available. Some financing statements included only the minimum amount of information required by statute. See note 16 supra. In most cases, a copy of the entire security agreement had been filed. 
Code

d) Interest rate (add-on):

$4.5 \%$
5.0
5.5
6.0
6.5
N.A.

Frequency Per cent

$\begin{array}{rc}61 & 26.0 \% \\ 37 & 15.7 \\ 15 & 6.4 \\ 101 & 43.0 \\ 4 & 1.7 \\ 17 & 7.2\end{array}$

6. Total number of months over which payments are to be made:

Less than 6 mos.
$6-12$ mos.
$12-18$ mos.
$18-24$ mos.
$24-36$ mos.
N.A.

7. Amount of monthly payments:

$\$ 0-50$
$51-60$
$61-70$
$71-80$
$81-90$
$91-100$
$101-110$
$111-150$
$150+$
NA

$\begin{array}{rc}4 & 1.7 \% \\ 11 & 4.7 \\ 6 & 2.6 \\ 24 & 10.2 \\ 174 & 74.0 \\ 16 & 6.8\end{array}$

$1.7 \%$

2.6

10.2

6.8

$\begin{array}{lll}\text { N.A. } & 18 & 7.6\end{array}$

8. Amount of last payment if more than $\$ 1$ different:

9. Name and address of assignee:

10. Name of cosigner, if any:

11. Contract signed by dealer: Yes

No

154

58

N.A.

23

$5.1 \%$

11.5

13.2

14.5

14.5

11.1

8.5

10.6

3.4

7.6 
APPENDIX G

\section{HVN AUTO LOANS} RELIEVE
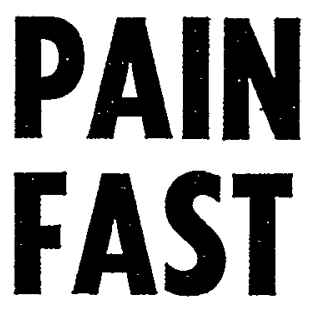

The Pain of High Auto Loan Interest Charges

For simplo relief from bigh auto financing charges, get an HVN auto lozn, No red lape. No wating. Deal direet with Huron Valley and izve add-en costs. Our rate is just $\$ 4.50$ per hundred per year, nwenty five pereant less than most? You save up to $\$ 157.50$, end have up to three years to rupay. Stop by and see us teday.

\begin{tabular}{|c|c|c|c|c|c|c|}
\hline \multirow{2}{*}{$\begin{array}{l}\text { Amint } \\
\text { fiesecod }\end{array}$} & \multicolumn{3}{|c|}{ TWO YEARS } & \multicolumn{3}{|c|}{ THREE YEARS } \\
\hline & $\begin{array}{l}\text { HWH } \\
\text { Monthy } \\
\text { Puyment }\end{array}$ & 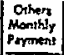 & 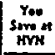 & $\begin{array}{c}\text { MVy } \\
\text { Monthy } \\
\text { Porments }\end{array}$ & $\begin{array}{l}\text { Ollowen } \\
\text { Honthy } \\
\text { Pryment }\end{array}$ & $\sin _{\sin }^{\gamma_{00}}$ \\
\hline$\$ 1,500$ & .64 .12 & 2000 & $\$ 5.00$ & 47.39 & 49.16 & 650 \\
\hline 2,000 & sans & $93 \times 3$ & $+\infty$ & 63.05 & osess & 20.00 \\
\hline 2,500 & 113.54 & 116.68 & 73500 & $78 s i$ & 21.94 & 11250 \\
\hline 3,500 & $15 a .95$ & 163.32 & 105.00 & 110.38 & 11022 & 10750 \\
\hline
\end{tabular}

\section{HURON VALLEY \\ National Bank. . the bank on the geves

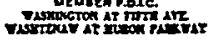

